\title{
Emmanuelia, a new genus of lobarioid lichen-forming fungi (Ascomycota: Peltigerales): phylogeny and synopsis of accepted species
}

\author{
Antoine Simon', Robert Lücking2, Bibiana Moncada³, Joel A. Mercado-Díaz ${ }^{4,5}$, \\ Frank Bungartz ${ }^{6,7,8}$, Marcela Eugenia da Silva Cáceres ${ }^{9}$, Emerson Luiz Gumboski ${ }^{10}$, \\ Suzana Maria de Azevedo Martins ${ }^{11}$, Adriano A. Spielmann ${ }^{12}$, Dinah Parker ${ }^{13,14}$ \\ \& Bernard Goffinet ${ }^{13^{*}}$
}

\section{Article info}

Received: 30 Jan. 2020

Revision received: 11 Mar. 2020

Accepted: 16 Mar. 2020

Published: 2 Jun. 2020

\section{Associate Editor}

Nicolas Magain

\begin{abstract}
The former family Lobariaceae, now included in Peltigeraceae as subfamily Lobarioideae, has undergone substantial changes in its generic classification in recent years, based on phylogenetic inferences highlighting the polyphyly of the speciose genera Lobaria, Pseudocyphellaria and Sticta. Here we introduce the new genus Emmanuelia, named in honor of Prof. Emmanuël Sérusiaux for his extensive work on the Peltigerales. Emmanuelia currently comprises twelve species. It is superficially similar to the lobarioid genus Ricasolia, but differs by its apothecia, rimmed by overarching and often crenulate to lobulate margins, with the parathecium (proper excipulum) and the amphithecium (thalline excipulum formed by the thallus cortex) apically separated and of a different structure. Also, ascospore dimensions and shape differ between the two genera, with the ascospores of Emmanuelia being longer and narrower. Molecular phylogenetic analyses using DNA nucleotide sequences of the internal transcribed spacer region (ITS) and the small subunit of mitochondrial ribosomal DNA (mtSSU) confirm that Emmanuelia belongs to the Lobaria s.lat. clade and forms a monophyletic group sister to the lineage consisting of Dendriscosticta, Lobariella and Yoshimuriella. None of the available generic names of lobarioid lichens can be applied to this group, and consequently a new name is proposed for this new genus, which is typified with E. ravenelii comb. nov. Eleven other species are transferred to Emmanuelia: E. americana comb. nov., E. conformis comb. nov., E. cuprea comb. nov., E. elaeodes comb. nov., E. erosa comb. nov., E. excisa comb. nov., E. lobulifera comb. nov., E. ornata comb. nov., E. patinifera comb. nov., E. pseudolivacea comb. nov. and $E$. tenuis comb. nov. The genus is represented in North America by three species, including $E$. lobulifera, which is resurrected from synonymy with $E$. (Lobaria) tenuis, a South American species, and E. ornata, whose populations were previously treated under E. (Lobaria) ravenelii.
\end{abstract}

Key words: Brazil, Dendriscocaulon, Lobarioideae, Neotropics, Peltigeraceae, Ricasolia, taxonomy, USA
${ }^{1}$ Evolution and Conservation Biology, InBIOS Research Center, University of Liège, Quartier Vallée 1, Chemin de la Vallée 4, B-4000 Liège, Belgium

${ }^{2}$ Botanischer Garten und Botanisches Museum, Freie Universität Berlin, Germany

${ }^{3}$ Universidad Distrital Francisco José de Caldas, Torre de Laboratorios, Herbario, Bogotá, 11021, Colombia

${ }^{4}$ Field Museum, Science and Education, Chicago, IL 60605, USA

${ }^{5}$ Committee on Evolutionary Biology, University of Chicago, 1025 E. 57th Street, Chicago, IL 60637, USA

${ }^{6}$ Biodiversity Integration Knowledge Center, Arizona State University, PO Box 874108, Arizona State University, Tempe, AZ 85287-4108, USA

${ }^{7}$ Instituto Nacional de Biodiversidad (INABIO), Quito, Ecuador

${ }^{8}$ Charles Darwin Foundation for the Galapagos Islands (CDF), Galápagos, Ecuador
${ }^{9}$ Departamento de Biociências, Universidade Federal de Sergipe, CEP: 49500-000, Itabaiana, Sergipe, Brazil

${ }^{10}$ Universidade da Região de Joinville, Departamento de Ciências Biológicas, Laboratório de Liquenologia, Rua: Paulo Malschitzki, $\mathrm{n}^{\circ} 10$ - Zona Industrial, CEP: 89219-710 - Joinville, SC, Brazil

${ }^{11}$ Fundação Zoobotânica do Rio Grande do Sul, Museu de Ciências Naturais, Porto Alegre, RS, Brasil

${ }^{12}$ Laboratório de Botânica / Liquenologia, Instituto de Biociências, Universidade Federal de Mato Grosso do Sul, CEP 79070-900, Campo Grande - MS, Brazil

${ }^{13}$ Department of Ecology and Evolutionary Biology, University of Connecticut, Storrs, CT 06269-3043, USA

${ }^{14}$ Department of Plant and Environmental Sciences, University of Copenhagen, Thorvaldsensvej 40, 1871 Frederiksberg, Denmark

* Corresponding author e-mail: bernard.goffinet@uconn.edu 


\section{Introduction}

Recent years have witnessed major systematic rearrangements of lobarioid lichens. In less than a decade, the number of genera circumscribed in this lineage of conspicuous macrolichens was multiplied by four. Essentially, the three long-established genera (Lobaria, Pseudocyphellaria, Sticta), which were diagnosed by single morphological features (the presence/absence of cyphellae or pseudocyphellae), did not survive the advent of molecular phylogenetics and were partitioned into twelve genera (Galloway \& Elix 2013; Moncada et al. 2013; Galloway 2015; McCune et al. 2014). As an example, moon lichens, which were characterized by the presence of crater-like pores on the lower cortex, are no longer considered as a monophyletic group under the genus name Sticta, as this trait evolved in two unrelated lineages. Thus, the genus Dendriscosticta, more closely related to Lobaria, was introduced to accommodate the additional lineage (Moncada et al. 2013).

In addition to the profound changes in generic concepts, lobarioid lichens were not spared from a recent systematic revision at the family level: in a recent study by Kraichak et al. (2018), under a temporal-banding proposal (Avise \& Johns 1999; Kraichak et al. 2017), the authors proposed treating the families Lobariaceae and Nephromataceae as synonyms of Peltigeraceae. While the mechanistic approach of temporal banding classifications has been criticized, the broad agreement in morphological, anatomical and chemical features and the absence of a clear diagnostic character for each of the three previously separated families justifies this revised classification (Lücking 2019). As a consequence, lobarioid lichens, long treated as Lobariaceae, are now recognized as members of the subfamily Lobarioideae within Peltigeraceae (Lumbsch \& Leavitt 2019).

In the present study, yet another new genus, Emmanuelia, is erected to accommodate a group of lobarioid lichens that cannot be placed in any of the existing genera. The species of interest belong to a lineage mostly restricted to the Neotropics and the southeastern United States, and were previously treated as members of the genus Lobaria and subsequently considered part of Ricasolia (Moncada et al. 2013; Käffer et al. 2016; Lehnen et al. 2017; Etayo et al. 2018). Yoshimura (1998) treated the South American taxa as L. quercizans group, also implying a close relationship to Ricasolia. This group of lichens includes, among others, shade-loving species of the Atlantic Forest biome in South America such as L. tenuis (Käffer et al. 2009), as well as $L$. ravenelii, a well-known taxon characteristic of the Atlantic-Gulf Coastal Plain in North America (Jordan 1973). To address their phylogenetic affinity, we reconstructed the phylogeny of the Lobaria s.lat. clade by using sequence data of two loci obtained from seven related genera of Lobarioideae. Our molecular analysis confirmed that $L$. ravenelii and other related species should be accommodated in a new segregated genus of Lobaria s.lat.

\section{Material and methods}

\section{Taxon sampling and phenotypic characterization}

The present study is based on detailed examination of lichen specimens provided by NY (William and Lynda Steere Herbarium, New York, USA) and numerous freshly collected specimens from fieldtrips to Brazil, the Caribbean Islands and Galapagos Islands. Thirty-four representatives of the taxonomic group of interest were selected based on preliminary phylogenetic analysis of the internal transcribed spacer region (ITS), along with ten specimens from related genera. Morphological features were observed at various laboratories, using various dissecting microscopes (Olympus SZ60, Leica Zoom 2000) and compound microscopes (Olympus BX53, Nikon Eclipse 80i, Zeiss Axioskop). Secondary chemistry was investigated through thin-layer chromatography (TLC) using solvent $\mathrm{G}$ and following the protocol by Orange et al. (2001). Detailed descriptions were provided for the generic type of the newly introduced genus (E. ravenelii) and for the resurrected species (E. lobulifera). For all other species we added short diagnostic descriptions.

\section{DNA extraction, amplification, and sequencing}

Genomic DNA was isolated using Nucleospin Plant II Midi kits (Macherey-Nagel, Bethlehem, Pennsylvania, USA), following the manufacturer's guidelines or following the protocol by Cubero et al. 1999. We amplified and sequenced the internal transcribed spacer region (ITS) using primers ITS1F (Gardes \& Bruns 1993) and ITS4 (White et al. 1990), and the small subunit of mitochondrial ribosomal DNA (mtSSU) using primers SSU1 and SSU3R (Zoller et al. 1999). Standard PCR protocols were carried out using GoTaq Green Master Mix (Promega, Madison, Wisconsin, USA), following the manufacturer's guidelines. The thermal cycling parameters were set as follows: $94^{\circ} \mathrm{C}$ for $3 \mathrm{~min}$, followed by $35-40$ cycles of $94^{\circ} \mathrm{C}$ for $1 \mathrm{~min}, 52^{\circ} \mathrm{C}$ for $1 \mathrm{~min}$ and $70^{\circ} \mathrm{C}$ for $1 \mathrm{~min}$, with a final extension of $70^{\circ} \mathrm{C}$ for $10 \mathrm{~min}$. The quality and size of the amplicons were visually checked on a $1 \%$ w/v agarose gel stained by SYBR Safe DNA Gel Stain (Thermo Fisher Scientific Inc., Waltham, Massachusetts, USA). Amplicons were cleaned using the ExoSAP-IT protocol (USB Corporation, Cleveland, Ohio, USA) and sequenced on a ABI Prism 3100 Genetic Analyzer (Applied Biosystems, Foster City, California, USA), or by Macrogen, Inc. (Seoul, South Korea). The forward and reverse sequences obtained were assembled and edited using Geneious 10.0.7 (Biomatters Ltd., Auckand, New Zealand) or Sequencher version 4.9 (Gene Codes Corporation, Ann Arbor, Michigan, USA). The resulting sequences were submitted to GenBank (Table 1).

\section{Alignment and sequences analyses}

The sequences generated for each gene were aligned with selected sequences from species of the Lobaria s.lat. clade from GenBank, using the genus Sticta as outgroup, in agreement with recent phylogenetic studies (e.g., Moncada et al. 2013; Widhelm et al. 2019; Table 1). The final 
Table 1. GenBank numbers and voucher information for specimens and sequences used in this study. Newly generated sequences are bolded.

\begin{tabular}{|c|c|c|c|c|}
\hline Species & ITS & $\mathrm{mtSSU}$ & Voucher & Origin \\
\hline Dendriscosticta aff. wrightii & MT110113 & MT110145 & Goffinet 13074 (CONN) & Taiwan \\
\hline D. praetextata & MT110112 & MT110144 & LS Wang, HX Shi 14-46246 (KUN) & China \\
\hline D. sp. & MT110111 & MT110143 & Goffinet 13005 (CONN) & Taiwan \\
\hline Emmanuelia aff. elaeodes & MT110106 & MT110138 & Mercado-Díaz 2939 (F) & Dominican Republic \\
\hline E. aff. elaeodes & MT110082 & - & Mercado-Díaz 3526a (F) & Jamaica \\
\hline E. aff. ravenelii & MT110107 & MT110139 & Mercado-Díaz 3031 (F) & Dominican Republic \\
\hline E. aff. tenuis & MT110089 & MT110125 & Lücking 37504 (B, JOI) & Brazil \\
\hline E. aff. tenuis & MT110096 & MT110132 & Lücking 39705 (B, ISE) & Brazil \\
\hline E. americana & MT110098 & - & Lücking 40112 (B, JOI) & Brazil \\
\hline E. elaeodes & MT110090 & MT110126 & Lücking 37511 (B, HAS) & Brazil \\
\hline E. elaeodes & MT110091 & MT110127 & Lücking 37544a (B, HAS) & Brazil \\
\hline E. elaeodes & MT110093 & MT110129 & Lücking 37546 (B, HAS) & Brazil \\
\hline E. elaeodes & MT110099 & - & Lücking 40082 (B, JOI) & Brazil \\
\hline E. elaeodes & MT110087 & MT110123 & Spielmann 11214 (B, CGMS) & Brazil \\
\hline E. erosa & MT110094 & MT110130 & Cáceres 25148 (B, ISE) & Brazil \\
\hline E. erosa & MT110097 & MT110133 & Mercado-Díaz 3038c (F) & Dominican Republic \\
\hline E. lobulifera & MT110076 & - & Kaminski 18013 (NY) & USA, Florida \\
\hline E. lobulifera & MT110100 & - & Lendemer 21578 (NY) & USA, Georgia \\
\hline E. lobulifera & MT110108 & MT110140 & Lendemer 41467 (NY) & USA, South Carolina \\
\hline E. lobulifera & MT110075 & - & Rosentreter 19739 (NY) & USA, Florida \\
\hline E. ornata & MT110085 & MT110121 & Moncada 8401(B, CDS) & Ecuador, Galapagos \\
\hline E. ornata & MT110086 & MT110122 & Moncada 8402 (B, CDS) & Ecuador, Galapagos \\
\hline E. ornata & MT110109 & MT110141 & Rosentreter 17651 (NY) & USA, Florida \\
\hline E. ornata & MT110074 & - & Rosentreter 20233 (NY) & USA, Florida \\
\hline E. patinifera & MT110101 & - & Cáceres 25182 (B, ISE) & Brazil \\
\hline E. ravenelii & MT110105 & MT110137 & Buck 63035 (NY) & USA, North Carolina \\
\hline E. ravenelii & MT110102 & MT110134 & Lendemer 34974 (NY) & USA, North Carolina \\
\hline E. ravenelii & MT110103 & MT110135 & Quendensley 10852 (NY) & USA, Georgia \\
\hline E. ravenelii & MT110104 & MT110136 & Tripp $4654(\mathrm{NY})$ & USA, North Carolina \\
\hline E. tenuis & MT110088 & MT110124 & Lücking 37502 (B, HAS) & Brazil \\
\hline E. tenuis & MT110092 & MT110128 & Lücking $37544 b$ (B, HAS) & Brazil \\
\hline E. tenuis & MT110095 & MT110131 & Lücking 40067 (B, JOI). & Brazil \\
\hline Lobaria isidiosa & MT110077 & MT110114 & LS Wang, HX Shi 14-46398 (KUN) & China \\
\hline L. isidiosa & MT110078 & MT110115 & LS Wang, HX Shi 14-46417 (KUN) & China \\
\hline L. linita & EU558809 & AB239702 & Högnabba et al. (2009), Takahashi et al. (2006) & - \\
\hline L. orientalis & MT110080 & MT110117 & LS Wang, HX Shi 14-45557 (KUN) & China \\
\hline L. orientalis & MT110079 & MT110116 & LS Wang, HX Shi 14-46123 (KUN) & China \\
\hline L. pulmonaria & AF069541 & AF129284 & Zoller et al. (1999) & - \\
\hline L. retigera & MT110081 & MT110118 & Goffinet 13103 (CONN) & Taiwan \\
\hline L. retigera & AY124159 & AY124094 & Lohtander et al. (2002) & - \\
\hline L. sachalinensis & EU558815 & AF524906 & Högnabba et al. (2009), Stenroos et al. (2003) & - \\
\hline Lobariella pallida & DQ912296 & HQ650695 & Miadlikowska et al. (2006), Schmull et al. (2011) & - \\
\hline L. pallidocrenulata & KC011075 & KC011051 & Moncada et al. (2013) & - \\
\hline L. reticulata & KC011076 & KC011063 & Moncada et al. (2013) & - \\
\hline L. subcrenulata & DQ912297 & HQ650696 & Miadlikowska et al. (2006), Schmull et al. (2011) & - \\
\hline L. subexornata & EU558804 & AF524902 & Högnabba et al. (2009), Stenroos et al. (2003) & - \\
\hline Lobarina oregana & MT110083 & MT110119 & Riley 7/20/04 DNA vouch. 4 (NY) & USA, Washington \\
\hline L. scrobiculata & AY340506 & AF350297 & Wiklund \& Wedin (2003), Thomas et al. (2002) & - \\
\hline L. silvae-veteris & MT110084 & MT110120 & Goward 04-05 (UBC) & Canada \\
\hline Ricasolia amplissima & AY340500 & AF524923 & Wiklund \& Wedin (2003), Stenroos et al. (2003) & - \\
\hline R. virens & MT110110 & MT110142 & Tønsberg 44757 (BG) & Norway \\
\hline Sticta sublimbata & JQ736019 & JQ735986 & Magain et al. (2012) & - \\
\hline S. sylvatica & KT281736 & KT281692 & Magain \& Sérusiaux (2015) & - \\
\hline Yoshimuriella aff. subdissecta & KC011073 & KC011029 & Moncada et al. (2013) & - \\
\hline Y. dissecta & EU558808 & AF524920 & Högnabba et al. (2009), Stenroos et al. (2003) & - \\
\hline
\end{tabular}

dataset contained representatives of all known genera within the Lobaria s.lat. clade. Alignment for each gene was assembled in Geneious 10.0.7 (Biomatters Ltd., Auckand, New Zealand) pre-aligned using MAFFT run in auto mode (Katoh 2002; Katoh et al. 2009), and the ends of each alignment were trimmed. The final matrices were obtained using default MAFFT settings, with two alignment iterations, as implemented in the Guidance Web Server (Penn et al. 2010a, b; Sela et al. 2015). Sites with low-quality scores (i.e., with confidence scores 
below 0.93 ) reported by GUIDANCE 2 were excluded from the datasets, which resulted in alignments of $589 \mathrm{bp}$ (initially $779 \mathrm{bp}$ ) and $700 \mathrm{bp}$ (initially $941 \mathrm{bp}$ ) for ITS and $\mathrm{mtSSU}$, respectively. As strongly supported topological conflicts were not observed when the loci were analyzed separately, the two markers were combined into a concatenated matrix of $1289 \mathrm{bp}$. The concatenated dataset included 55 terminals, all represented by ITS, and 47 of which were also represented by the mtSSU marker. PartitionFinder 2 (Lanfear et al. 2016) was used to determine the best partitioning schemes and nucleotide substitution models for the subsequent maximum likelihood (ML) analysis on the concatenated dataset. Two initial subsets were considered (ITS, mtSSU) and the default configuration settings were used (branchlengths $=$ linked, models $=$ GTR+G, model_selection = AICc) with the greedy algorithm (Lanfear et al. 2012) and PhyML (Guindon et al. 2010). An ML analysis was performed on the 2-gene dataset using RAxML-HPC2 8.2.12 (Stamatakis 2014) on the CIPRES portal (Miller et al. 2010; https://www. phylo.org), using the rapid hill-climbing algorithm and bootstrapping with 1000 pseudoreplicates under a GTR+G model of evolution for each subset provided by PartitionFinder 2 (subset 1: ITS; subset 2: mtSSU).

Relationships among the Emmanuelia elaeodes species aggregate (E. americana, E. elaeodes, E. ravenelii, E. tenuis) remained largely unresolved in our ML phylogenetic tree (Fig. 1A). For this reason, we constructed a haplotype network for these closely related species, using the TCS v1.21 program (Clement et al. 2000) as implemented in PopART software (Leigh \& Bryant 2015). The ITS sequences of these species were re-aligned using the general MAFFT settings as implemented in the Guidance Web Server. Since the resulting alignment contained relatively few ambiguous portions, the dataset was loaded with all sites included. Sites with undefined states were then masked, and sequences containing significantly more undefined states than others were removed from the analysis.

Based on the 2-gene dataset, a strict molecular clock model was employed to date the evolutionary origin of the genus Emmanuelia, using the Bayesian program BEAST 1.10.4 (Drummond \& Rambaut 2007). We initially conducted a run using a relaxed, log-normal, uncorrelated clock: this preliminary run supported a clock-like rate of evolution, as the standard deviation estimate of the clock (i.e., the 'ucld.stdev' parameter estimate) was close to zero. Consequently, a strict clock prior was applied. The dataset was analyzed with unlinked substitutions models across the two loci, and the most appropriate nucleotide substitution model for each locus was determined based on the AICc model selection criterion as implemented in jModelTest2 (Darriba et al. 2012) and using five substitution schemes (ITS: TrN+I+G; mtSSU: HKY+I+G). A Yule prior was assigned to the speciation process (Yule 1924; Gernhard 2008). The 'ucld.mean' prior (mean substitution rate) was set to a diffuse gamma distribution (shape 0.001 , scale 1000). The time to the most recent ancestor ('tmrca') for the ingroup node (Lobaria s.lat. clade) was calibrated at $57.6 \mathrm{myr}$, using a normal prior distribution with the standard deviation set to 13 myr; this calibration followed the results of the time-calibrated Lobariaceae phylogeny by Widhelm et al. (2019). All other priors were held to default values. The BEAST analysis was run for 50 million generations, sampling parameters every 5000 steps, and performed on the CIPRES Science Gateway (Miller et al. 2010). Convergence, mixing, and effective sample sizes (ESS) of parameters were checked in Tracer 1.6 (Rambaut et al. 2014). All ESS values were above 200. A burn-in of $10 \%$ was discarded from the run. A maximum credibility tree with a cut-off of 0.5 of posterior probabilities was generated with the remaining 9,000 trees in TreeAnnotator version 1.10.4 (BEAST package). The results of the ML and Bayesian analyses were visualized with the R package ggtree (Yu et al. 2017).

\section{Results}

Emmanuelia emerged as a strongly supported monophyletic group (ML bootstrap support $[\mathrm{BS}]=100$, posterior probabilities $[\mathrm{PP}]=1$ ) on a fairly long branch within the Lobaria s.lat. clade (Fig. 1A). In contrast, backbone support values within Emmanuelia were low, suggesting a rather recent radiation. Emmanuelia was recovered as sister to a clade consisting of Dendriscosticta, Lobariella and Yoshimuriella by both ML and Bayesian inferences, and not directly related to Ricasolia, justifying the introduction of a new genus to accommodate this group of lichenized fungi. Within Emmanuelia, strong support was obtained for a clade of four species: E. americana, E. elaeodes, E. ravenelii and E. tenuis. Relationships within this clade remained mostly unresolved under ML. The TCS haplotype network (Fig. 1B) for 13 specimens within the E. elaeodes species aggregate further highlighted the lack of signal in the ITS marker to segregate these species (with the exception of $E$. ravenelii, which appeared well-differentiated in both TCS and ML analyses).

The strict molecular clock analysis estimated the crown node age of the genus Emmanuelia at 10.2 myr in the late Miocene (95\% high probability density [HPD]: 4.0-17.8 myr; Fig. 2). The stem node age of Emmanuelia versus its sister clade (Dendriscosticta + Lobariella + Yoshimuriella) was estimated at 29.8 myr in the early Oligocene (HPD: 11.1-48.2 myr).

Although Ricasolia is not directly related to Emmanuelia, it is morphologically most similar to the latter, whereas the related genera Dendriscosticta, Lobariella and Yoshimuriella are easily distinguished. Yet, analyses of morphological and anatomical characters revealed a number of subtle differences between Emmanuelia and Ricasolia. In Emmanuelia the apothecial margins are typically overarching and lobulate, with a rough outer surface, whereas in Ricasolia they are slightly prominent, more or less entire, and with a smooth outer surface. In Emmanuelia the parathecium (i.e., proper excipulum) appears to be apically separated from the amphithecium (i.e., thalline excipulum formed by the thallus cortex) by the photobiont layer which reaches up to the apex, and also different in structure (prosoplectenchymatous vs. paraplectenchymatous; Fig. 3A-B). In Ricasolia the 


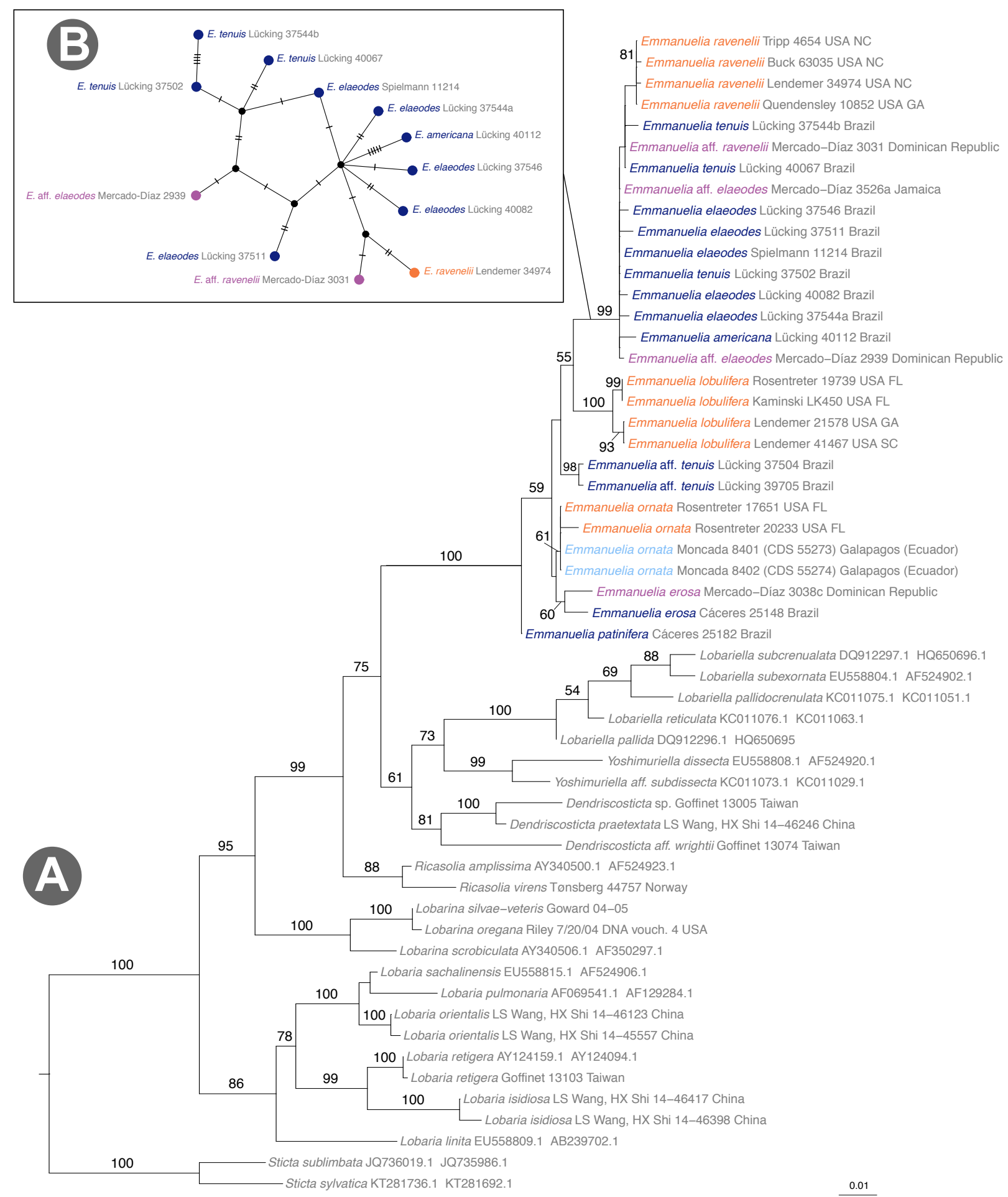

Figure 1. A - Best-scoring phylogenetic tree of the genus Emmanuelia within the Lobariaceae family, obtained from inferences of two-loci molecular data (ITS, mtSSU). Values above branches represent ML bootstrap values (indicated when greater than or equal to 50). Colors in taxa names of Emmanuelia spp. represent sample origin (Brazil: dark blue; Mainland United States: orange; Caribbean: purple; Galapagos Islands: light blue). B - Relationships among Emmanuelia intermedia complex ITS haplotypes, using statistical parsimony networks as implemented in TCS. Each colored circle represents one observed haplotype and one individual. Individuals whose sequences contained significantly more undefined states than others were removed. Circles are color-coded by origin. Hatch marks and black dots represent hypothetical haplotypes needed to connect the network but not observed among the samples.

parathecium and amphithecium are apically connected, due to the photobiont layer stopping short below the apex, and at least the upper part of the parathecium is paraplectenchymatous (Fig. 3C-D). A further difference is found in the ascospores, with those of Emmanuelia generally acicular and arranged in a bundle and those of
Ricasolia fusiform and irregularly arranged to uniseriate. In the three common species of Ricasolia the ascospores are as follows: $45-60 \times 4-5 \mu \mathrm{m}, \sim 9-12$ times as long as broad ( $R$. quercizans), 40-60 × 5-7 $\mu \mathrm{m}, \sim 7-9$ times as long as broad (R. amplissima), and 25-45 $\times 6-10 \mu \mathrm{m}$, $\sim 4-5$ times as long as broad ( $R$. virens). By contrast, for 


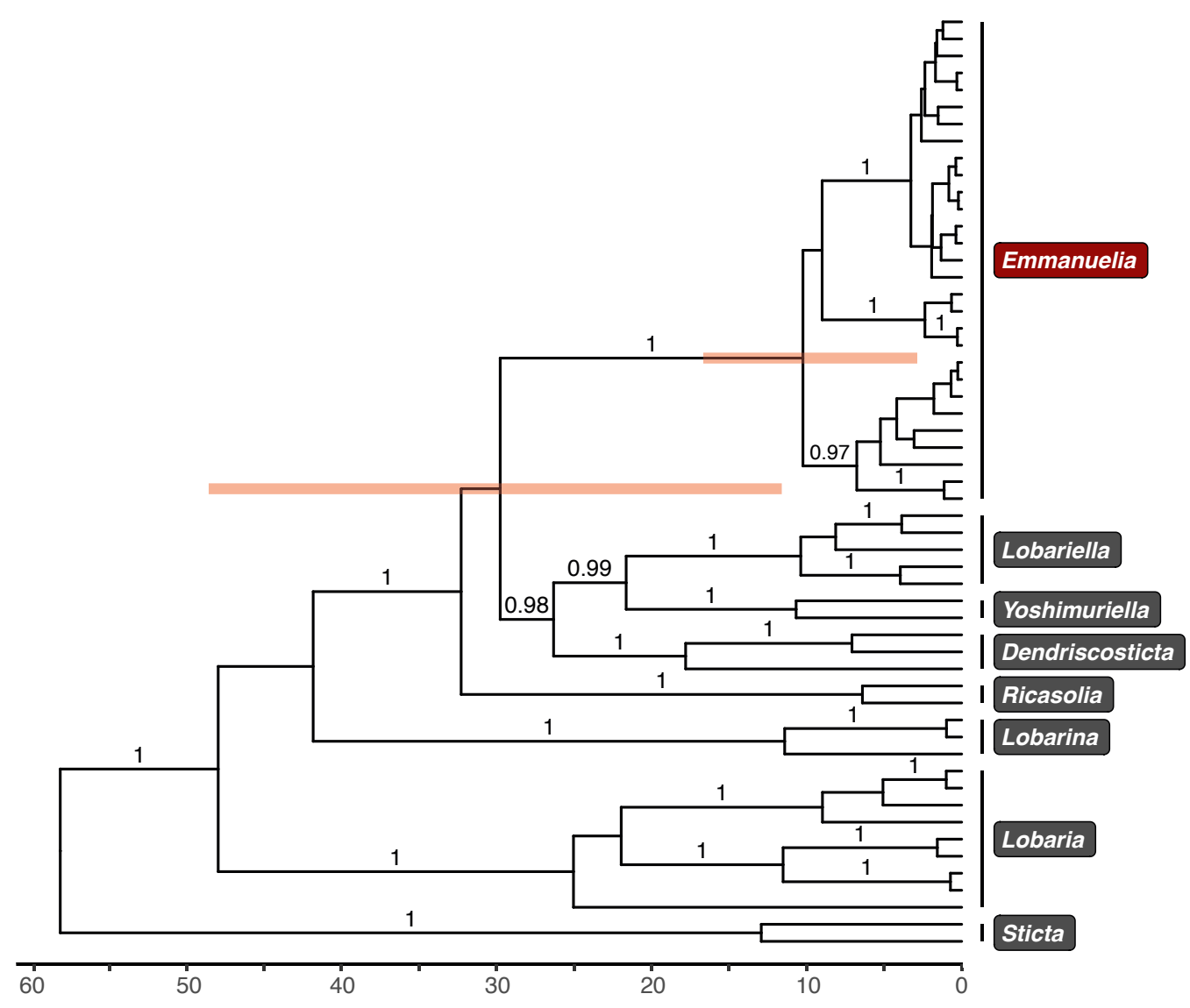

Figure 2. Strict molecular clock tree of the Lobaria s.lat. clade, showing origin and diversification of Emmanuelia. Red-brown bars indicate the 95\% posterior density interval of crown and stem node age for the genus Emmanuelia. Values above branches represent posterior probabilities (indicated when greater than or equal to 0.95 ). Scale at bottom: millions of years before present.

sequenced species of Emmanuelia the following values were observed: $60-75 \times 2.5-3 \mu \mathrm{m}, \sim 20-25$ times as long as broad (E. ravenelii), 60-80 × 2-3 $\mu \mathrm{m}, \sim 20-30$ times as long as broad (E. elaeodes), 60-70 $\times 3-3.5 \mu \mathrm{m}$, $\sim 15-20$ times as long as broad (E. tenuis), and 50-80 $\times$ 2.5-4 $\mu \mathrm{m}, \sim 17-22$ times as long as broad (E. patinifera). Somewhat similar measures, with length between 55 and $80 \mu \mathrm{m}$, width between 3 and $4 \mu \mathrm{m}$, and length/width ratio between 15 and 25, were reported in the literature for E. americana, E. cuprea, E. pseudolivacea and E. tenuis (e.g., Yoshimura \& Osorio 1975; Fig. 4). Thus, while the overall variation between the two genera appears to be gradual, ascospores of Emmanuelia tend to be longer and relatively narrower than those of Ricasolia.

\section{Discussion}

Under two different tree-building strategies, the new genus Emmanuelia forms a well-supported monophyletic group restricted to the New World and sister to a lineage consisting of Dendriscosticta, Lobariella and Yoshimuriella. This result, and the overall tree topology, agree with the phylogenomic analysis of the Lobarioideae (as Lobariaceae) by Widhelm et al. (2019). Their study and ours have in common three representatives of Emmanuelia. These shared samples are here referred to as E. aff. elaeodes, E. aff. ravenelii and E. erosa (Mercado-Díaz 2939, 3031, 3038c), and as Ricasolia spp. (15682, 15683, 15685) in Widhelm et al. (2019). Both inferences, drawn from distinct sets of loci, recovered the focal lineage in a cluster further comprising the three aforementioned genera, and hence independently supporting the establishment of the new genus. In fact, the newly introduced genus, whose representatives were treated as species of Lobaria until now, are not closely related to either Lobaria or Ricasolia, although morphologically it is most similar to the latter (Yoshimura 1998). Since no generic or infrageneric name is available for this clade, we introduce the genus Emmanuelia, currently comprising the following twelve species: E. americana, E. conformis, E. cuprea, E. elaeodes, E. erosa, E. excisa, E. lobulifera, E. ornata, E. patinifera, E. pseudolivacea, E. ravenelii and E. tenuis. Emmanuelia ravenelii is designated as the nomenclatural type for the genus, since this is probably the best-documented species of the lineage and its identification is straightforward.

The low backbone support for phylogenetic relationships within Emmanuelia may be due to a recent rapid radiation, an evolutionary scenario recently highlighted within the Lobarioideae (Lücking et al. 2017b; Simon et al. 2018). Based on our time-calibrated phylogeny, this clade emerged approximately 10 million years ago in the late Miocene, making this one of the younger genera within the Lobarioideae (Widhelm et al. 2019). However, other related genera such as Lobariella, Lobarina, 
Ricasolia and Yoshimuriella have similar crown ages, whereas Dendriscosticta and particularly Lobaria s.str. appear to be older. The fairly restricted geographic distribution of Emmanuelia, as compared to other more widespread related genera, tends to support the scenario of a recent diversification. Notably, the crown divergence time for Emmanuelia coincides with the onset of the uplift of the northern Andes (Hoorn et al. 2010). The latter may explain the rather recent diversification of genera such as Lobariella (Moncada et al. 2013), but most of the Emmanuelia species occur in the Atlantic Forest of southeastern Brazil, in a geologically much older formation (Peucker-Ehrenbrink \& Miller 2007; Brotzu et al. 2007; Colombo \& Joly 2010). Possibly the recent diversification of Emmanuelia largely in the Atlantic Forest, with subsequent expansion northwards, is related to paleoclimatic events, as apparent from other groups of organisms in this biome with similarly recent diversification times (e.g., Fouquet et al. 2012; Batalha-Filho et al. 2013; Machado et al. 2018).

Low taxonomic resolution possibly resulting from recent diversification is particularly evident in the E. elaeodes aggregate, where morphological identifications do not necessarily correspond to phylogenetic topology (with the exception of E. ravenelii). Two possible reasons for this may be offered: (1) the ITS and mtSSU markers may not be sufficiently informative to disentangle species within this complex, or (2) this complex may represent a single species with morphological variation. In particular, E. tenuis may represent the phyllidiate counterpart of E. elaeodes. Further studies are needed to resolve the taxonomy of this complex.

\section{Taxonomy}

Emmanuelia Ant. Simon, Lücking \& Goffinet, gen. nov. MycoBank MB 834643

Diagnosis: A lobarioid genus lacking cyphellae, pseudocyphellae and maculae, with a short, \pm uniform lower tomentum (no veins), primarily associated with a green alga, sometimes with a dendriscocauloid cyanomorph, with gyrophoric acid (major) and 4-O-methylgyrophoric acid (congyrophoric acid; minor or absent) as secondary compounds. Morphologically and chemically similar to the genus Ricasolia, but differing in the apothecia with overarching margin and separation of the parathecium and amphithecium, consistently narrower and longer, acicular ascospores, and a subtropical to tropical distribution. Molecularly, the new genus is characterized by a short, unique rDNA sequence motif within the highly conserved $5.8 \mathrm{~S}$ region in the ITS. The section defining Emmanuelia is as follows (deviations underlined):

5-CGAATCATCGAATCTTTGAACGCACATTGCGCCCCYYGGYAㅌ-3.
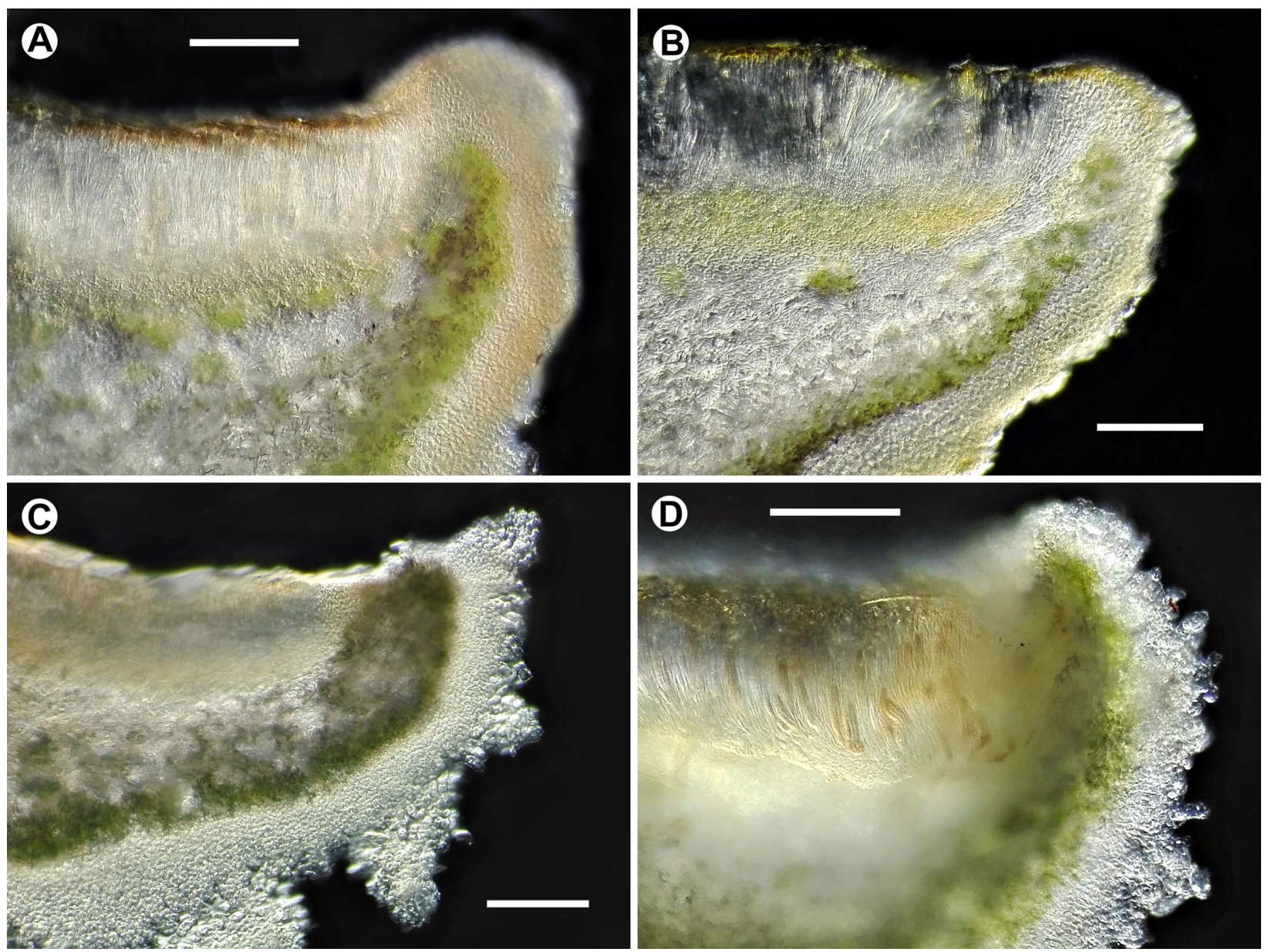

Figure 3. Apothecial sections in Emmanuelia and Ricasolia. A-B - R. quercizans (A, Wetmore 83137) and R. virens (B, Sipman 1742), showing the parathecium apically connected with the amphithecium; C-D - E. ravenelii (Harris 14938) and E. elaeodes (Lücking 37544a), showing the parathecium apically separated from the amphithecium by the photobiont layer. Scale $=100 \mu \mathrm{m}$. 


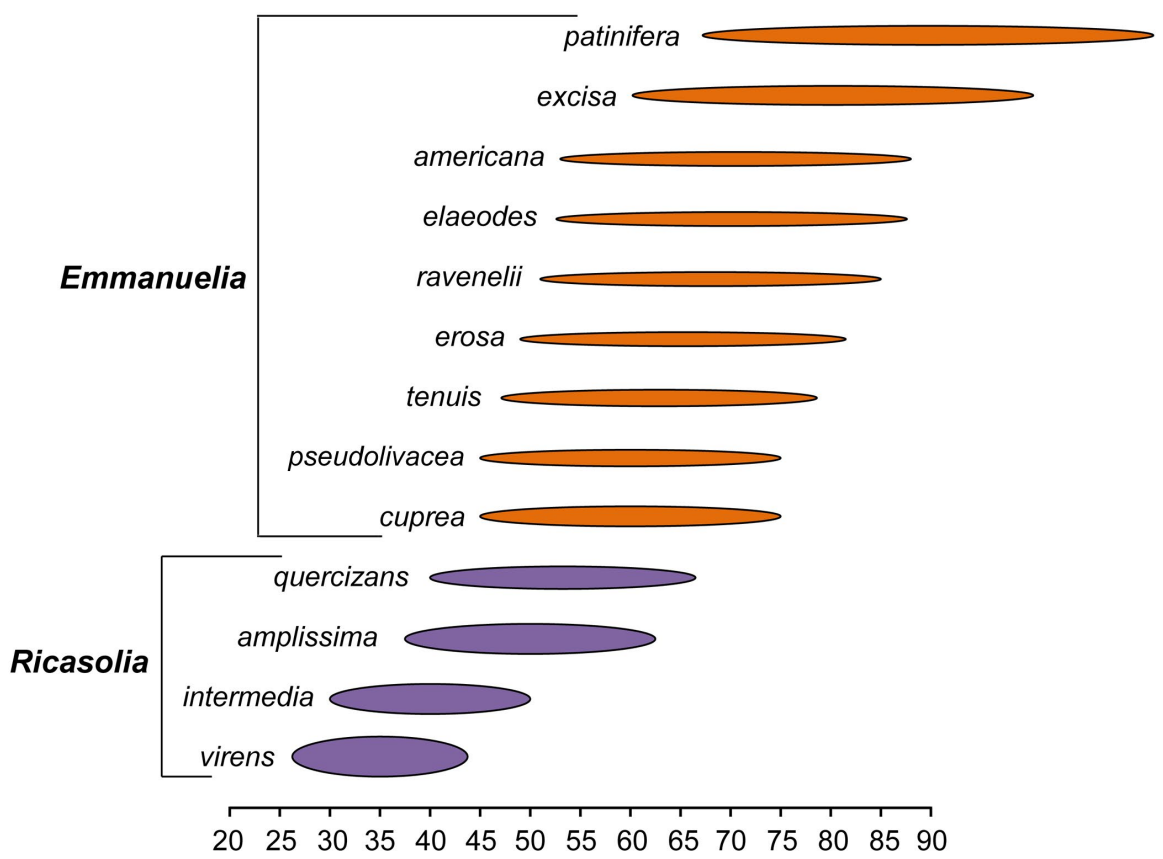

Figure 4. Comparison of ascospore dimensions in Ricasolia and Emmanuelia. Each ellipse indicates mean ascospore length and width; the ellipses are positioned according to their mean length.

Generic type: Emmanuelia ravenelii (Tuck.) Ant. Simon \& Goffinet

Etymology. The new taxon is named in honor of Prof. Emmanuël Sérusiaux, for his extensive contributions to advancing our understanding of the diversification of the Peltigerales.

Comments. Morphologically, Emmanuelia can be easily differentiated from Lobaria s.str. by the tomentum on the lower surface and the shape of the ascospores (Yoshimura 1998; Moncada et al. 2013). However, the newly introduced genus is quite similar to Ricasolia. In particular, like some species of Ricasolia, at least one species of Emmanuelia, E. ornata (previously often identified with the name Lobaria patinifera), produces dendriscocauloid cyanomorphs emerging from the green-algal thallus (e.g., Jordan 1972; Tønsberg et al. 2016; Fig. 6C-D). The two genera differ in their geographical distribution and ecology: Emmanuelia is a subtropical to tropical taxon found from southeastern North America to southern South America, whereas Ricasolia appears to be a strictly temperate, Northern Hemisphere taxon (Cornejo et al. 2017); the two genera are somewhat sympatric in the southeastern United States, but Emmanuelia replaces Ricasolia in coastal areas (Jordan 1973).

Morphologically, Emmanuelia differs from Ricasolia by its apothecia, rimmed by overarching and often crenulate to lobulate margins with a rough surface, whereas in Ricasolia the margins are only slightly prominent, more or less entire, and with a smooth surface, an observation also noted by Yoshimura (1998) when comparing tropical species of his 'Lobaria quercizans group' to Ricasolia quercizans s.str. Anatomically, in Emmanuelia the parathecium (proper excipulum) appears to be apically separated from the amphithecium (formed by the thallus cortex), by the photobiont layer reaching up to the apex, and also different in structure (prosoplectenchymatous vs. paraplectenchymatous), a characteristic referred to as 'apothecium type II' (Yoshimura 1971; Yoshimura \& Osorio 1975). In Ricasolia the parathecium and amphithecium are apically connected, due to the photobiont layer stopping short distinctly below the apex, and at least the upper part of the parathecium is paraplectenchymatous. A further difference is found in the ascospores, with those of Emmanuelia generally acicular and arranged in a bundle and those of Ricasolia fusiform and irregularly arranged to uniseriate.

Below we provide brief diagnostic descriptions and comments for ten of the 12 species included in the new genus, and more detailed accounts for the type species, E. ravenelii, and the reinstated eastern North American E. lobulifera.

Emmanuelia americana (Vain.) Lücking, Moncada \& Gumboski, comb. nov.

(Fig. 5A)

MycoBank MB 834644

Basionym: Lobaria americana Vain., Acta Soc. Fauna Fl. Fenn. 7(1): 195. 1890.

Type: Brazil, Minas Gerais: Serra do Caraca; $1400 \mathrm{~m}$, 1885, Vainio 1187 (TUR-V10666 - lectotype!, here selected; MBT391290; M-M0207349 - isolectotype!).

Diagnostic description. Primary photobiont a trebouxioid alga. Thallus medium-sized to large, rather loosely adnate, composed of irregularly arranged lobes. Lobes leathery, rather broad, up to $12 \mathrm{~mm}$ wide, sinuose with \pm rounded apices. Upper surface \pm even but often with abundant pycnidial warts, glabrous. Lower surface thinly tomentose except for bare marginal zone, tomentum brown. Apothecia scattered, laminal, to $7 \mathrm{~mm}$ in diam., 

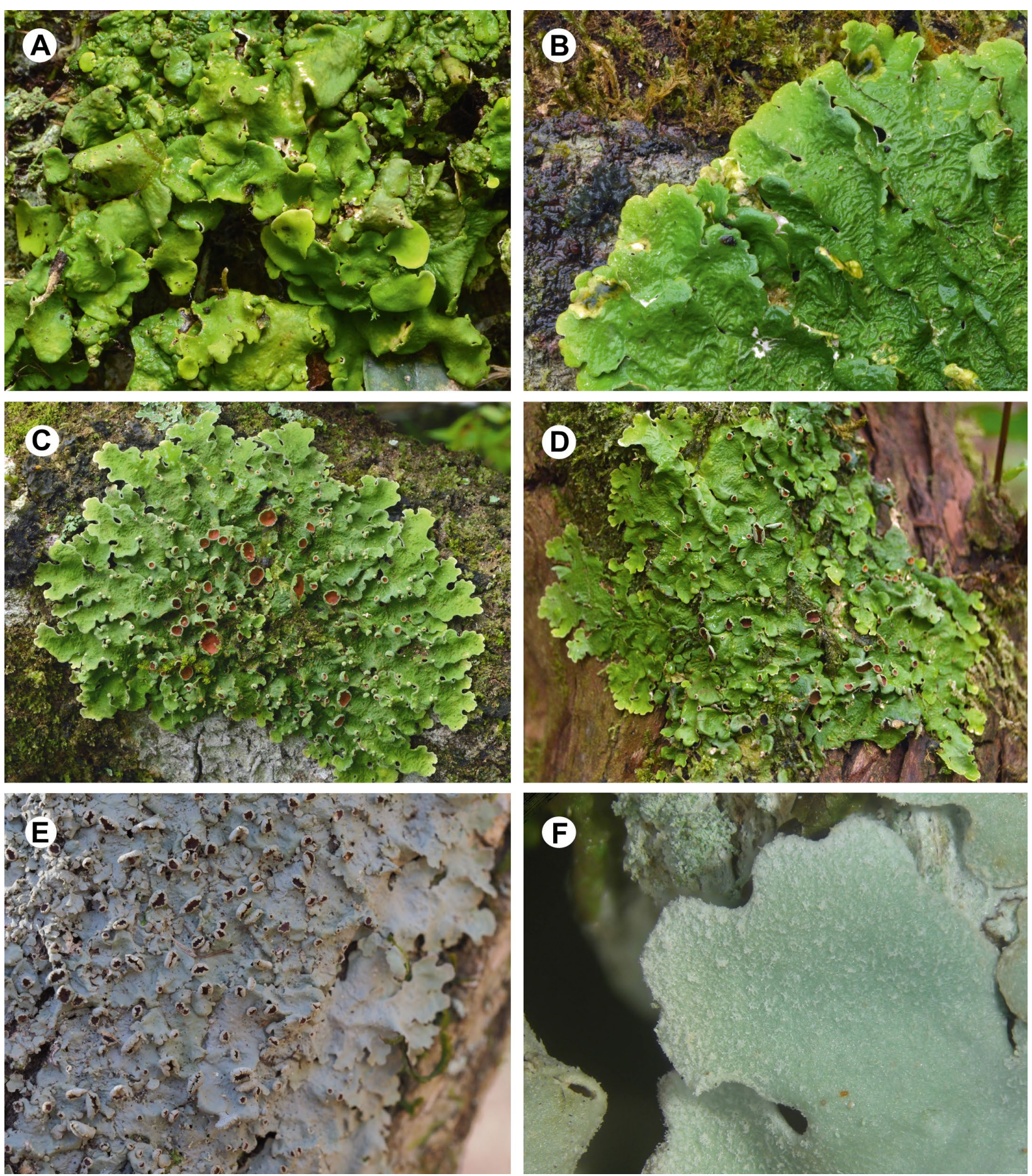

Figure 5. Habit of Emmanuelia species. A - E. americana (Lücking 40112), showing upper side with pycnidial warts; B - E. erosa (Cáceres 25148), showing upper side with distinct scrobiculate surface; C-D - E. elaeodes (C, Lücking 40082; D, Lücking 37546), showing upper side with apothecia; E-F - E. ravenelii (Hollinger 2332, CONN), showing upper side with numerous apothecia (E) and close-up of lobe margins with pruinose surface (F). Photographs E \& F: courtesy of Jason Hollinger.

margin strongly prominent, lobulate. Ascospores acicular, straight to slightly curved, 1(-3)-septate, $60-80 \times$ $2.5-3 \mu \mathrm{m}, \sim 20-30$ times as long as broad.

Secondary chemistry. Gyrophoric acid (major).

Comments. This species is intermediate between Emmanuelia patinifera and E. elaeodes in thallus and lobe size and in the development of a lobulate apothecial margin, but has generally a thicker thallus with a leathery appearance. While molecular data and morphology clearly separate E. elaeodes from E. patinifera, E. americana is phylogenetically close to $E$. elaeodes.

Specimens examined. BRAZIL. Santa Catarina: São Francisco do Sul, Parque Estadual Acarai; $26^{\circ} 16^{\prime} \mathrm{S}, 48^{\circ} 32^{\prime} \mathrm{W}$, sea level; rather well preserved coastal Restinga forest; 8 October 2015, Lücking 40112 (B, JOI). São Paulo: Guapiara, Serra Paranapiacaba, Fazenda Intervales, just W of 'Sede de Pesquisas'; $24^{\circ} 16^{\prime} \mathrm{N}, 48^{\circ} 25^{\prime} \mathrm{W}, 800 \mathrm{~m}$; hilly, humid forest along stream; 23 July 1991, D. M. Vital \& W. R. Buck 20429 (B).

Molecular data. Yes. 
Emmanuelia conformis (Nyl.) Lücking, Moncada \& Ant. Simon, comb. nov.

\section{MycoBank MB 834645}

Basionym: Lobaria conformis Vain., Dansk Bot. Ark. 4(11): 16. 1926.

Types: Mexico, Veracruz: Totutla, Mirador, Aguas Santos; 1841, Liebmann 7545 (TUR-V10658 - lectotype!, here selected, MBT391291). [Mexico] Veracruz: Totutla; 1841, Liebmann 7546 (TUR-V10659 - paratype!). Pico de Orizaba; 1841, Liebmann 7564 (TUR-V10660!). Huatusco; 1841, Liebmann 7565 (TUR-V10663 - paratype!), Liebmann 7570 (TUR-V10664 - paratype!). Mirador; 1842, Liebmann 7581 (TUR-V10661, TUR-V10662 - paratypes!).

Diagnostic description. Primary photobiont a trebouxioid alga. Thallus small, closely adnate, composed of \pm radiating lobes. Lobes narrow, up to $3 \mathrm{~mm}$ wide, sinuose with undulate margins and rounded apices. Upper surface \pm even, glabrous. Lower surface thinly tomentose except for narrow, bare marginal zone, tomentum greyish brown. Apothecia frequent, laminal, to $3 \mathrm{~mm}$ in diam., margin prominent, shallowly crenulate. Ascospores acicular, straight to slightly curved or sigmoid, 3-5-septate, $70-80 \times 2-3 \mu \mathrm{m}, \sim 25-35$ times as long as broad.

Secondary chemistry. Gyrophoric acid (major).

Comments. This material was first considered conspecific with Emmanuelia elaeodes (see comments below) but differs in the overall much smaller size and in the 3-5-septate ascospores, as well as in its distribution. Yoshimura (1998) considered Lobaria conformis a synonym of L. patinifera, with the latter name in his treatment being misapplied to what is here recognized as E. ornata. However, E. conformis differs from both E. ornata and E. patinifera (see key below). Notably, several studies had reported $L$. conformis as a separate species prior to Yoshimura's (1998) treatment (e.g., Osorio \& Fleig 1987; Sipman 1993).

\section{Molecular data. No.}

Emmanuelia cuprea (Müll. Arg.) Lücking, Moncada \& Ant. Simon, comb. nov.

MycoBank MB 834646

Basionym: Ricasolia cuprea Müll. Arg., Revue Mycol. 10(38): 55. 1888.

Types: Paraguay, 'Cordillère de Péribébuy’ [sic]; Jul 1879, Balansa 4211 (G-G00292338 - lectotype!; G-G00292342 isolectotype!). [Brazil] Rio Grande do Sul: without locality, Blumenau s.n. (G-G00292344 - paratype!).

$\equiv$ Lobaria cuprea (Müll. Arg.) Zahlbr., Cat. Lich. Univers. 3: 299. 1925.

Diagnostic description. Primary photobiont a trebouxioid alga. Thallus medium-sized, rather closely adnate, composed of \pm radiating lobes. Lobes intermediate, up to $10 \mathrm{~mm}$ wide, sinuose with rounded apices. Upper surface \pm even, glabrous. Lower surface thinly tomentose except for bare marginal zone, becoming purplish red in the herbarium, tomentum greyish brown. Apothecia scattered, laminal, to $8 \mathrm{~mm}$ in diam., margin strongly prominent, shallowly to deeply crenulate. Ascospores acicular, straight to slightly curved or sigmoid, 1-septate, 55-65 $\times$ $3.5-4 \mu \mathrm{m}, \sim 15$ times as long as broad.

Secondary chemistry. Gyrophoric acid (major) and unknown purple pigment appearing post-mortem after rewetting (Yoshimura \& Osorio 1975).

Comments. This taxon is characterized by the purplish red color of the underside in rewetted herbarium specimens (Yoshimura \& Osorio 1975; Osorio \& Fleig 1987); this corresponds to a specific pigment detectable by TLC (Yoshimura \& Osorio 1975). A similar effect has been reported for, e.g., Cora rubrosanguinea from Ecuador (Lücking et al. 2017a).

\section{Molecular data. No.}

Emmanuelia elaeodes (Malme) Lücking, Spielmann \& S. M. Martins comb. nov.

(Fig. 5C-D)

\section{MycoBank MB834647}

Basionym: Lobaria elaeodes Malme, Ark. Bot. 26A(14): 4. 1935 .

Type: Brazil, Mato Grosso: Serra da Chapada, Buriti; 25 Jun 1894, Malme 2492b (S-L1564 - holotype!).

Diagnostic description. Primary photobiont a trebouxioid alga. Thallus medium-sized, rather closely adnate, composed of \pm radiating lobes. Lobes intermediate, up to $7 \mathrm{~mm}$ wide, sinuose with rounded to truncate apices. Upper surface \pm even, glabrous except for sometimes scattered tiny hairs near the apices. Lower surface thinly tomentose except for narrow, bare, whitish marginal zone, tomentum greyish brown. Apothecia frequent, laminal, to $3 \mathrm{~mm}$ in diam., margin strongly prominent, shallowly to deeply crenulate. Ascospores acicular, straight to slightly curved or sigmoid, 1(-3)-septate, $60-80 \times 2.5-3 \mu \mathrm{m}$, $\sim 20-30$ times as long as broad.

Secondary chemistry. Gyrophoric acid (major), 4-O-methylgyrophoric (congyrophoric) acid (minor).

Comments. We first named the Brazilian material Ricasolia intermedia, a species described from Mexico. The type material of Lobaria elaeodes, Ricasolia intermedia, and $L$. conformis, also described from Mexico, all agree in thallus morphology and lobe disposition. However, after discovering the differences in ascospore size and shape between Emmanuelia and Ricasolia, we noticed that the ascospores of $R$. intermedia, not given in the protologue, were described as rather short and broad by Stizenberger (1895), namely $\sim 35-45 \times 10 \mu \mathrm{m}, \sim 3.5-4.5$ times as long as broad. On the type material, also rather broad ascospores are depicted, without measurements but $\sim 7$ times as long as broad. In contrast, the ascospores of the types of $L$. elaeodes and $L$. conformis fit those of Emmanuelia. Therefore we consider $R$. intermedia a genuine member of that genus, whereas the Brazilian material represents the genus Emmanuelia and must bear 
the epithet elaeodes. The Mexican L. conformis is also considered a species of Emmanuelia but it differs from E. elaeodes by the smaller thallus with narrower lobes and the multiseptate ascospores.

Specimens examined. BRAZIL. Rio Grande do Sul: Caraá, Caraá Environmental Protection Area; $29^{\circ} 42^{\prime} \mathrm{S}, 50^{\circ} 17^{\prime} \mathrm{W}, 410 \mathrm{~m}$; well-preserved Atlantic Forest fragment; 21 September 2014, Lücking 37511, 37545, 37544a, 37546 (B, HAS). Santa Catarina: São Francisco do Sul, Parque Estadual Acarai; 26 ${ }^{\circ} 16^{\prime} \mathrm{S}$, $48^{\circ} 32^{\prime} \mathrm{W}$, sea level; rather well preserved coastal Restinga forest; 8 October 2015, Lücking 40082, 40112 (B, JOI).

Molecular data. Yes.

Emmanuelia erosa (Eschw.) Lücking, M. Cáceres \& Ant. Simon, comb. nov.

(Fig. 5B)

MycoBank MB 834648

Basionym: Parmelia erosa Eschw. in Martius, Fl. Bras. Enum. Pl. 1(1): 211. 1833.

Type: Brazil, Minas Gerais: Without locality ('serro frio'); Martius s.n. (M-M0024300 - holotype!).

$\equiv$ Ricasolia erosa (Eschw.) Nyl., Syn. Meth. Lich. 1(2): 371. 1860.

三Lobaria erosa (Eschw.) Trevis., Lichenoth. Veneta 1-2: 75. 1869. 1882.

$\equiv$ Sticta erosa (Eschw.) Tuck., Syn. N. Amer. Lich. 1: 93.

$\equiv$ Lobaria quercizans var. erosa (Eschw.) Vain., Acta Soc. Fauna Fl. Fenn. 7(1): 196. 1890.

Diagnostic description. Primary photobiont a trebouxioid alga. Thallus small to medium-sized, closely adnate, composed of irregular to \pm radiating lobes. Lobes narrow, up to $5 \mathrm{~mm}$ wide, with truncate apices. Upper surface distinctly scrobiculate, glabrous. Lower surface thinly tomentose except for bare marginal zone, tomentum greyish brown. Apothecia frequent, laminal, to $5 \mathrm{~mm}$ in diam., margin strongly prominent, lobulate but lobules caducous. Ascospores acicular, straight to slightly curved or sigmoid, 1-septate, $60-70 \times 2.5-3 \mu \mathrm{m}, \sim 20-25$ times as long as broad.

Secondary chemistry. Gyrophoric acid (major).

Comments. This is a rather characteristic species, which in the past had been synonymized with Emmanuelia (as Lobaria) ravenelii and even Ricasolia quercizans (e.g., Stizenberger 1895), but its rather narrow, scrobiculate lobes are distinctive and its separation is supported by molecular data.

Specimens examined. BRAZIL. Rio de Janeiro: Itatiata National Park, Agulhas Negras road, $\mathrm{km} 8$ on road to Agulhas Negras, $32 \mathrm{~km} \mathrm{NW}$ of Itatiaia, roadside; $22^{\circ} 21^{\prime} \mathrm{S}, 44^{\circ} 44^{\prime} \mathrm{W}$, 2150 m; Atlantic Rain Forest, small roadside forest fragment near Araucaria stand, on bark; 6 May 2015, M. E. S. Cáceres et al. 25148 (B, ISE). São Paulo: Praia do Lázaro bei Ubatuba; $2 \mathrm{~m}$; in einem hellen und trockenen Stranddünenwald (Restinga); 29 September 1979, K. Kalb (B; distributed in Lichenes Neotropici, no. 237, as Lobaria ravenelii).

Molecular data. Yes.
Emmanuelia excisa (Müll. Arg.) Lücking, Moncada \& Ant. Simon, comb. nov.

MycoBank MB 834649

Basionym: Sticta excisa Müll. Arg., Flora 74: 375. 1891.

Type: Colombia, unknown locality; on rotten trunk; Blagborne s.n. (M-M0207328 - lectotype!, here selected, MBT391292; G-G00294960 - isolectotype!).

$\equiv$ Ricasolia excisa (Müll. Arg.) Stizenb., Flora 81: 112. 1895.

$\equiv$ Lobaria excisa (Müll. Arg.) Zahlbr., Catal. Lich. Univers. 3: 301.1925.

Diagnostic description. Primary photobiont a trebouxioid alga. Thallus medium-sized to large, closely adnate, composed of radiating lobes. Lobes intermediate, up to $10 \mathrm{~mm}$ wide, sinuose with undulate margins and rounded to crenulate apices. Upper surface \pm even to somewhat canaliculate, glabrous. Lower surface dense and very regularly tomentose except for narrow, bare, pale marginal zone, tomentum dark brown. Apothecia frequent, laminal, to $5 \mathrm{~mm}$ in diam., margin strongly prominent, distinctly lobulate. Ascospores acicular, straight to slightly curved, 1-3-septate, $70-90 \times 3.5-4 \mu \mathrm{m}, \sim 20-25$ times as long as broad.

Secondary chemistry. Gyrophoric acid (major).

Comments. Müller (1891) described Sticta excisa from Colombia and Jamaica. There are three syntypes in G (Colombia, Jamaica) and M (Colombia). The material from Jamaica does not bear apothecia, so its identity cannot be ascertained. Therefore the well-developed specimen from Colombia in $\mathrm{M}$ was selected as lectotype. Emmanuelia excisa is somewhat intermediate between E. patinifera and E. elaeodes but it differs from the first in the narrower, radiating, adnate lobes and smaller, horizontal apothecia, and from the second in the more robust thallus and distinctly lobulate apothecial margins. The ascospores of E. excisa are the among the broadest thus far known in the genus, but still narrower than those of Ricasolia quercizans (Fig. 4).

Specimen examined. COLOMBIA. Casanare: Chámeza, Vda. Mundo Viejo, finca El Triunfo; $5^{\circ} 11^{\prime} 39^{\prime \prime} \mathrm{N}, 72^{\circ} 54^{\prime} 06^{\prime \prime} \mathrm{W}$, 1450 m; on bark; 24-31 January 2012, L. Vargas \& J. Herrera 551 (UDBC-C-0004830).

\section{Molecular data. No.}

Emmanuelia lobulifera (B. Moore) Ant. Simon \& Goffinet, comb. nov.

(Fig. 6A-B)

\section{MycoBank MB 834650}

Basionym: Lobaria lobulifera B. Moore, The Bryologist, 72(3): 404. 1969.

Types: USA, Florida, Citrus County: Yulee Sugar Mill, Moore 1042 (DUKE - holotype!; US - isotype!). Columbia County: Junction of Florida Highway 6 and US Highway 441, Hale 21777 (US - paratype!); O'Leno State Park, Hale 16436 (US - paratype!). Duval County: Jacksonville, Calkins 38 (US - paratype!). Flagler County: Near Bunell, Moore 2440 (DUKE - paratype!). Orange County: Rock Springs, Moore 3772a (DUKE - paratype!). 

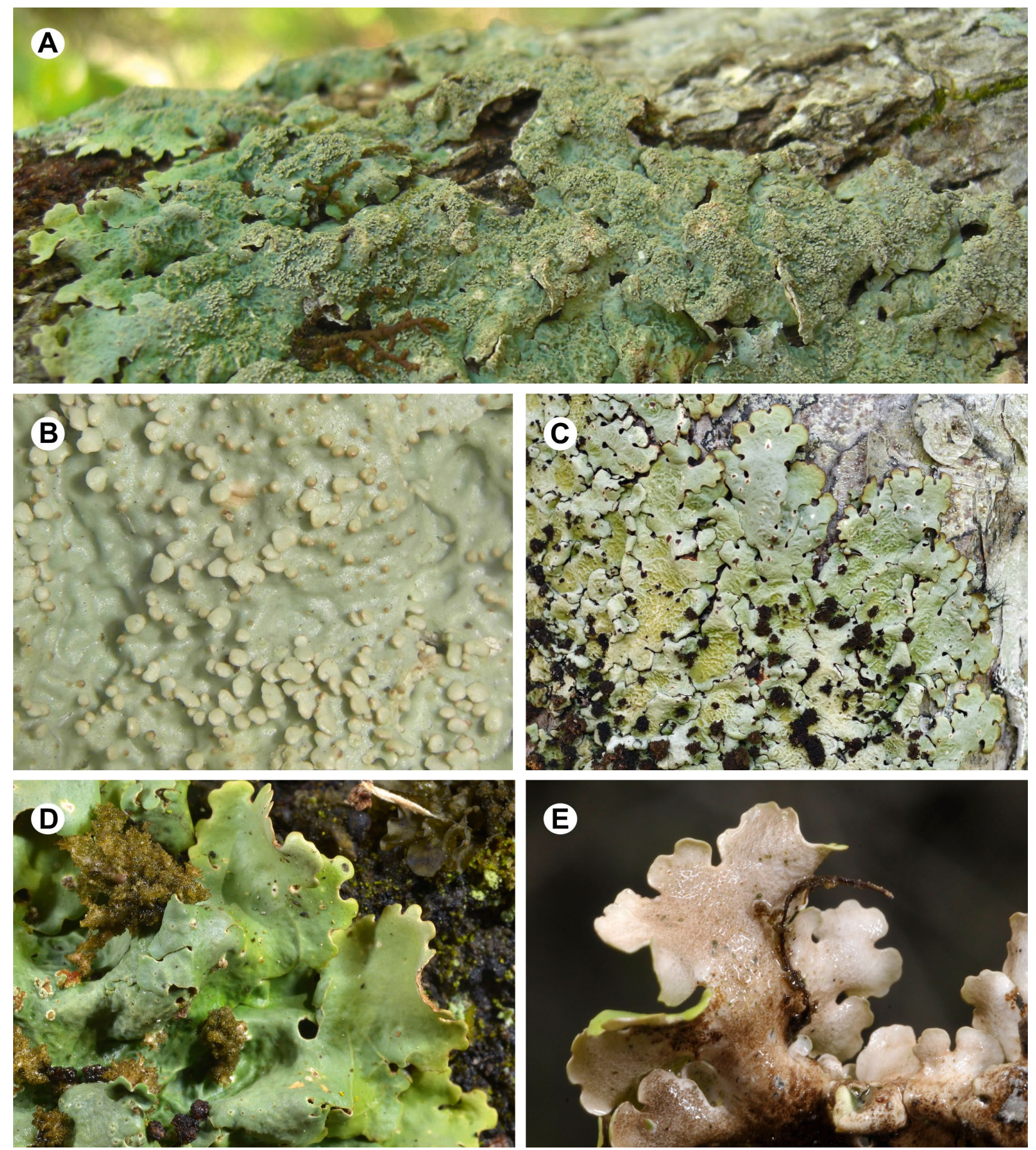

Figure 6. Habit of Emmanuelia species. A-B - E. lobulifera (Hollinger 2542), showing upper side with sparsely branched phyllidia (A) and phyllidia enlarged (B); C-E - E. ornata, showing upper side with dendriscocauloid cephalodia (C, Moncada 8401, CDS 55273), cephalodia enlarged (D, Bungartz 10972, CDS 55363), and lower side (E, Bungartz 10244, CDS 47663). Photographs A, B: courtesy of Jason Hollinger.

Description. Primary photobiont a trebouxioid alga. Thallus irregular in outline, small to medium-sized, to $8 \mathrm{~cm}$ diam., composed of radiating, stiff, repeatedly branched and spreading lobes. Lobes adjacent to imbricate and overlapping, from $1 \mathrm{~mm}$ wide at branching point and to $5 \mathrm{~mm}$ wide above, with truncate to spatulate apices, adnate, with free, plane margins; margins entire, occasionally with small simple lobules inward. Upper surface smooth, glabrous, light greenish or rarely brownish grey and light brownish towards margin when dry, greenish when wet, matte; margin lacking pruina. Phyllidia mostly laminal, somewhat obliquely oriented, squamiform, almost orbicular to palmate, mostly unbranched to sparsely branched, either at base or along margin bearing one or more lobules, or dichotomously branched, typically $\sim 0.5 \mathrm{~mm}$ in diam., to $1 \mathrm{~mm}$ long. Medulla rather compact, white, $\mathrm{KC}+$ pink. Cephalodia (with Nostoc) internal, globose, to $0.2 \mathrm{~mm}$ in diameter. Lower surface smooth at margin, rugose, verrucose inward, thinly tomentose, with hairs in short fascicules, light brown to cream-colored. Rhizines simple, abundant to scattered, to $0.8 \mathrm{~mm}$ long, whitish, darkening inward. Apothecia not observed. Upper cortex paraplectenchymatous, $20-30 \mu \mathrm{m}$ thick, homogeneous, consisting of 4-6 cell layers. Photobiont 
layer $15-30 \mu \mathrm{m}$ thick, its cells $\sim 6 \mu \mathrm{m}$ diam. Medulla 60-100(120) $\mu \mathrm{m}$ thick. Lower cortex paraplectenchymatous, 15-20 $\mu \mathrm{m}$ thick, with 3 cell layers; surface papillose to microtomentose in section in between short fascicles.

Secondary chemistry. Gyrophoric acid (major), 4-O-methylgyrophoric acid (minor).

Ecology and distribution. On hardwood trees on the coastal plain of the southeastern United States.

Comments. Our study revealed that Lobaria lobulifera (Moore 1969), previously synonymized under L. tenuis, is a distinct species, here resurrected as E. lobulifera. The shared presence of phyllidia led Yoshimura (1971) and Jordan (1973) to synonymize the two taxa, but both the position of the phyllidia (largely laminal vs. marginal) and their shape (squamiform vs. elongate) differ between E. lobulifera and E. tenuis, and their distinction is supported by phylogenetic data. The different distribution of the two taxa provides another argument, with $E$. tenuis mostly known from Brazil (e.g., Lücking 37544b, 40067), including the type, and E. lobulifera from the southeastern United States (e.g., Kaminski LK450, Lendemer 21578, 41467, and Rosentreter 19739), with its type collected in Florida (Moore 1969).

Specimens examined. USA. Alabama, Covington Co., Conecuh National Forest, Solon Dixon Forestry Education Center, Cave Road, $31.1864^{\circ},-86.6972^{\circ}$, extensive limestone outcroppings, mesic hardwoods, on trunk of Fagus, 2007 April 14, W. R. Buck 51821 (NY \#919534); Florida, Levy Co., N end of Gulf Hammock, along St. Rd. 24, 7.5 mi SW of US 19/98 at Otter Creek, $29^{\circ} 16^{\prime} \mathrm{N}, 82^{\circ} 52^{\prime} \mathrm{W}$, hardwood-Taxodium swamp, on Fraxinus, 1995 December 31, R. C. Harris 37160 (NY); Suwannee Co., Peacock Springs State Recreation Area, off 180th Street $2.2 \mathrm{mi}$ E of FL 51 at Luraville, $30^{\circ} 07^{\prime} \mathrm{N}, 83^{\circ} 08^{\prime} \mathrm{W}$, upland hardwood forest around limestone springs, on old fallen oak, 1996 December 2, R. C. Harris 39371 (NY); Georgia, Appling Co. Moody Forest Natural Area, $0-0.5 \mathrm{mi} \mathrm{E}$ of head of River Trail on Miller Landing Rd., $0.75 \mathrm{mi}$ N of jct w/ E River Road, $31.9167,-82.2681$, oak scrub with pine and occasional larger hardwoods, on Liquidambar, 2009 December 17, J. C. Lendemer 21063 (NY \#1151402); Effingham Co., Craig Barrow farm, $32.3526^{\circ},-81.4804^{\circ}$, north-aspect sandhill bluff, on bark, 2012 March 4, M. F. Hodges 8274 (NY \#2057448); Emanuel Co., Ohoopee Dunes Natural Area, McLeod Bridge tract, $0.5 \mathrm{mi}$ $\mathrm{W}$ of intersection of McLeod Bridge Road and Old McLeod Bridge Road, E shore of the Little Ohoopee River, $32.6028^{\circ}$, $-82.4292^{\circ}$, oak scrub on white sand dunes grading into mixed hardwood forest, on Quercus, 2009 December 19, J. C. Lendemer 21288 (NY \#1150245); Tattnall Co., Big Hammock Natural Area, blue and yellow trails, $\sim 1 \mathrm{mi}$ E of jet of CR 441 \& GA $121 / 144 / 169,31.8576^{\circ},-82.0589^{\circ}$, sandhill community with oak scrub and mixed hardwoods, on Quercus, 2009 December 20, J. C. Lendemer 21434 (NY \#1150291); Wayne Co., Sansavilla Wildlife Management Area, Boat Launch below Alex Creek, SW shore of Altamaha River, $31.5111^{\circ},-81.6667^{\circ}$, steep mesic riverine bluff mixed hardwood forest (Ilex, Carya, Quercus, Magnolia, Nyssa) with NE aspect, on Carya base, 2009 December 21, J. C. Lendemer 21575 (NY \#1150405); South Carolina, Berkeley Co., Francis Marion National Forest, Guilliard Lake Scenic Area, E of Gravel Run, W of FS 150-G, $0.5 \mathrm{mi} \mathrm{S}$ of terminus at Guilliard Lake and $0.3 \mathrm{mi} \mathrm{SW}$ of jet w/ FS 190, $33.2814^{\circ},-79.6244^{\circ}, 20$, upland mixed hardwood (Acer, Quer- cus, Liquidambar, Ilex opaca, I. laevigata, Myrica) and Pinus forest, on Quercus, 2013 December 6, J. C. Lendemer 41467 (NY \#2327058).

\section{Molecular data. Yes.}

Emmanuelia ornata (Malme) Lücking, Moncada \& Bungartz, comb. nov.

(Fig. 6C-E)

\section{MycoBank MB 834652}

Basionym: Lobaria ornata Malme, Ark. Bot. 26A (14): 5a. 1935.

Type: Brazil, Minas Gerais: São João del Rei; 1 Sep 1892, Malme 303 (S-L1557)

Diagnostic description. Primary photobiont a trebouxioid alga. Thallus medium-sized, closely adnate, composed of radiating lobes. Lobes narrow, up to $5 \mathrm{~mm}$ wide, with rounded to truncate apices. Upper surface \pm even to shallowly scrobiculate towards center, glabrous. Lower surface thinly tomentose except for a bare, whitish marginal zone, tomentum brown. Apothecia not observed.

Secondary chemistry. Gyrophoric acid (major), 4-O-methylgyrophoric (congyrophoric) acid (minor).

Comments. This species is here reported for the first time from the United States and the Galapagos Islands. North American material was previously considered a form of Lobaria ravenelii with erumpent cephalodia (Jordan 1973). In tropical America this taxon was mostly named L. patinifera, but the type of the latter is entirely different from the material with narrow, adnate lobes and cephalodia to which this name has been applied (see below). The dendriscocauloid cephalodia are reminiscent of those of Ricasolia species, and since apothecia are apparently absent in this species, it cannot be readily assigned to Emmanuelia without molecular data.

\section{Molecular data. Yes.}

Emmanuelia patinifera (Taylor) Lücking, M. Cáceres \& Ant. Simon, comb. nov.

(Fig. 7A)

MycoBank MB 834653

Basionym: Parmelia patinifera Taylor, London J. Bot. 6: 172. 1847.

Type: Brazil, Rio de Janeiro: Serra dos Órgãos; Gardner et al. 1002 (G-G00291728 - isotype!).

$\equiv$ Ricasolia patinifera (Taylor) Müll. Arg., Flora 71: 24. 1888.

三Sticta patinifera (Taylor) Müll. Arg., Flora 74: 111. 1891.

$\equiv$ Lobaria patinifera (Taylor) Hue, Nouv. Arch. Mus. Hist. Nat., Paris, 4, Sér. 3: 29. 1901.

= Sticta casarettiana De Not., Mém. R. Accad. Sci. Torino, Ser. 2 12: 158. 1851.

= Squamaria casarettiana (De Not.) A. Massal., Atti Inst. Veneto Sci. lett., ed Arti, Sér. 3, 5: 250. 1860.

= Ricasolia casarettiana (De Not.) Nyl., Acta Soc. Sci. Fenn. 7(2): 438. 1863.

= Lobaria casarettiana (De Not.) Trevis., Lichenoth. Veneta: no. 75.1869.

= Ricasolia erosa var. casarettiana (De Not.) Nyl., Flora 52: 314. 1869. 
= Ricasolia quercizans var. casarettiana (De Not.) Stizenb., Flora 81: 112. 1895.

= Lobaria quercizans f. casarettiana (De Not.) Zahlbr., Cat. Lich. Univers. 10: 272. 1939.

Type: Brazil, Rio de Janeiro: Serra dos Órgãos; Casaretto 851 (H-NYL 33432 - H-H9506039 - isotype!).

= Ricasolia erosa var. laevis Müll. Arg., Flora, Regensburg 63: 264. 1880.

Type: Brazil, Rio de Janeiro: Without locality; 1878, Glaziou 2789 (G-G00294980 - lectotype!, here selected, MBT391293).

= Lobaria quercizans f. aequalis Vain., Acta Soc. Fauna Fl. Fenn. 7(1): 196. 1890.

Type: Brazil, Minas Gerais: Sitio; 1000 m; 1885, Vainio 954 (TUR-V10651 - holotype!).

Diagnostic description. Primary photobiont a trebouxioid alga. Thallus large, loosely adnate, composed of irregularly arranged to somewhat radiating lobes. Lobes broad, up to $20 \mathrm{~mm}$ wide, with rounded to truncate apices. Upper surface uneven, glabrous. Lower surface thinly tomentose except for a broad, bare, whitish marginal zone, tomentum greyish brown. Apothecia frequent, laminal, to $10 \mathrm{~mm}$ in diam., typically obliquely arranged (almost as in Peltigera species), margin strongly prominent, coarsely lobulate, the parathecium in section formed by peculiar, thick, palisadic hyphae that break up under pressure into separate 'hairs'. Ascospores acicular, straight to slightly curved, 3-septate, $85-95 \times 3.5-4 \mu \mathrm{m}, \sim 20-25$ times as long as broad.

Secondary chemistry. Gyrophoric acid (major).

Comments. The name Lobaria patinifera has been commonly misapplied to specimens with an adnate thallus, with narrow lobes and forming abundant, dendriscocauloid cephalodia. Revision of type material revealed that Emmanuelia patinifera is characterized by rather broad, loosely attached lobes, large, distinctly lobulate apothecia, and lack of external cephalodia. The type material of Sticta casarettiana and the other taxonomic synonyms listed here correspond well to this morphology. The ascospores of E. patinifera were described as 3-7-septate by some authors, but this was likely based on either wrongly identified specimens or misinterpretation of the septa of the very narrow ascospores. Typically the ascospores are 1-septate, occasionally 3-septate. Emmanuelia patinifera is a peculiar species, emerging from the earliest split in the genus in our ML tree: it has the largest thallus and most robust lobes, as well as the largest apothecia and ascospores in the genus; the apothecia are obliquely oriented, and the parathecium (proper exciple) is formed by peculiar, thick, palisadic hyphae. Magain et al. (2012) reported this species from Reunion (Mascarene archipelago), but the ITS sequence generated does not fall into Emmanuelia and their specimen may belong to Lobariella.

Specimens examined. BRAZIL. Minas Gerais: Itatiaia National Park, Agulhas Negras road, $\mathrm{km} 4$ on road to Agulhas Negras, $34 \mathrm{~km} \mathrm{NW}$ of Itatiaia, roadside; $22^{\circ} 22^{\prime} \mathrm{S}, 44^{\circ} 45^{\prime} \mathrm{W}$, 1980 m; Atlantic Rain Forest, shady roadside forest margin, on bark; 6 May 2015; M. E. S. Cáceres et al. 25182 (B, ISE).

Molecular data. Yes.
Emmanuelia pseudolivacea (Zahlbr.) Lücking, Moncada \& Ant. Simon, comb. nov.

\section{MycoBank MB 834651}

Basionym: Lobaria pseudolivacea Zahlbr., Cat. Lich. Univers. 3: 309. 1925.

Types: Brazil, Minas Gerais: Sitio; 1000 m; 1885, Vainio 376 (TUR-V10641 - lectotype!, here selected, MBT391295; TUR-V10642 - isolectotype!; M-M0207704 - isolectotype!). [Brazil] Minas Gerais: Sitio; 1000 m; 1885, Vainio 984 (TURV10643 - paratype!).

= Ricasolia olivacea Stizenb., Flora 81: 111. 1895 [nom. illeg., ICN Art. 53; non Ricasolia olivacea (Dufour) Bagl.].

= Lobaria olivacea Vain., Acta Soc. Fauna Fl. Fenn. 7(1): 197. 1890 [nom. illeg., ICN Art. 53; non Lobaria olivacea Hoffm.]; [nom. illeg., ICN Art. 52]

Diagnostic description. Primary photobiont a trebouxioid alga. Thallus medium-sized, closely adnate, composed of irregularly arranged lobes. Lobes narrow, up to $5 \mathrm{~mm}$ wide, often almost laciniate. Upper surface uneven, glabrous. Lower surface thinly tomentose except for narrow, bare marginal zone, tomentum greyish brown. Apothecia frequent, laminal, to $10 \mathrm{~mm}$ in diam., margin prominent, crenulate to lobulate. Ascospores acicular, straight to slightly curved, 1-septate, 55-65 × 3-3.5 $\mu \mathrm{m}, \sim 15-20$ times as long as broad. No lichen substances.

Secondary chemistry. No substances detected by TLC.

Comments. This species is characterized by the rather narrow lobes combined with large apothecia, and the lack of secondary substances, an unusual feature in the genus, which is otherwise chemically uniform.

Molecular data. No.

Emmanuelia ravenelii (Tuck.) Ant. Simon \& Goffinet, comb. nov.

(Fig. 5E-F)

\section{MycoBank MB 834654}

Basionym: Sticta ravenelii Tuck., Amer. J. Sci. Arts, Ser. 2, 28: 203. 1859.

Type: USA, South Carolina: without locality; Ravenel s.n. (FH - lectotype!, here selected, MBT391294; US-US00432748 - isolectotype!). Cuba, without locality; Wright 66 p.p. (USUS00433359 p.p. - paratype!).

三 Ricasolia ravenelii (Tuck.) Nyl., Acta Soc. Sci. Fenn. 7(2): 438. 1863.

三Lobaria ravenelii (Tuck.) Yoshim., J. Hattori Bot. Lab. 34: 320. 1971.

Description. Primary photobiont a trebouxioid alga. Thallus irregular in outline, small to medium to $11 \mathrm{~cm}$ diam., of radiating, stiff, repeatedly branched and spreading lobes. Lobes adjacent to imbricate and overlapping, to $5 \mathrm{~mm}$ wide between main dichotomies, with truncate to spatulate apices, adnate, with free, slightly broadly involute margins; margins entire, occasionally with small simple lobules inward. Upper surface smooth to scrobiculate, glabrous, light greenish or rarely brownish grey and light brownish toward margin when dry, 

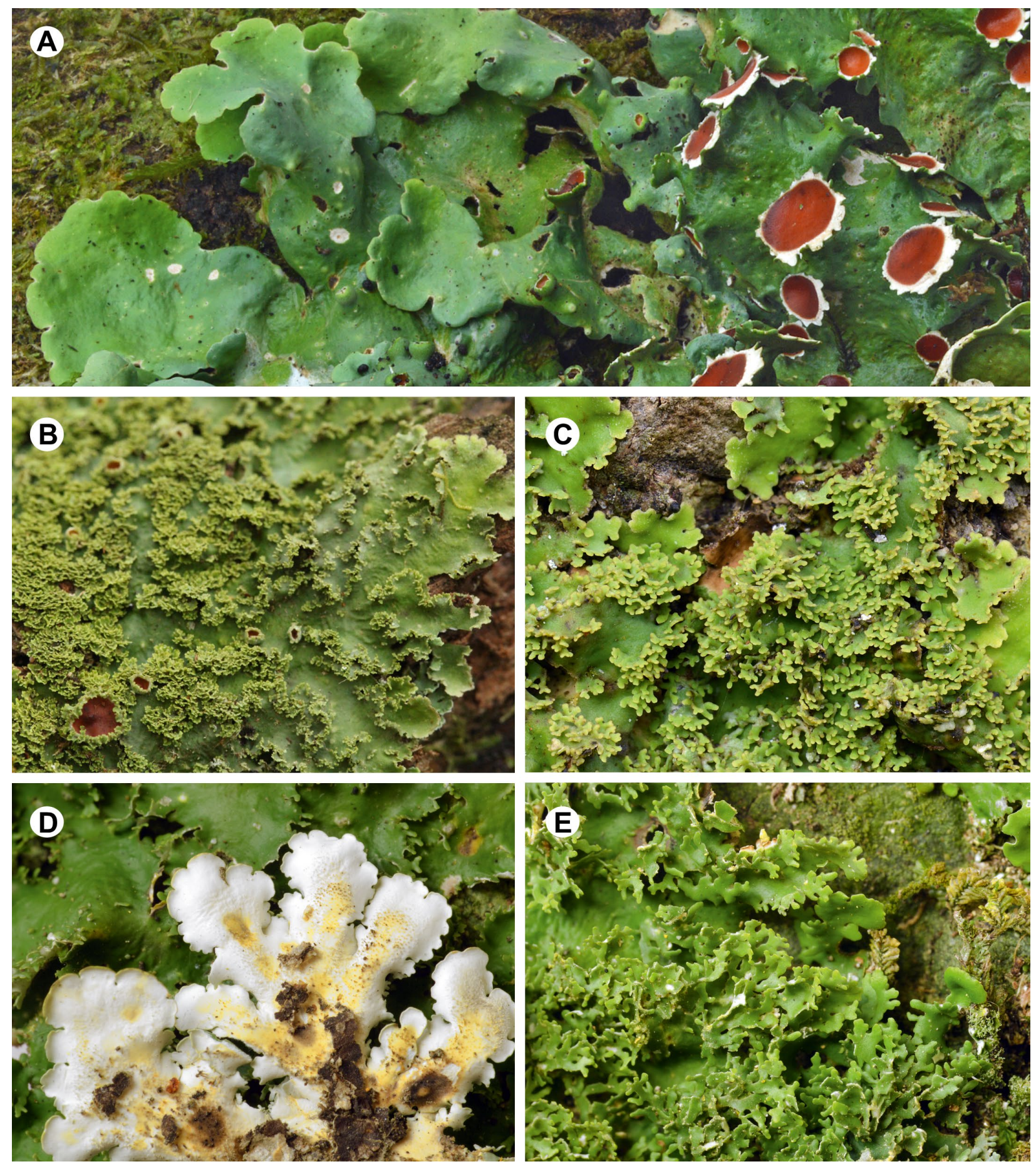

Figure 7. Habit of Emmanuelia species. A - E. patinifera (Cáceres 25182), showing upper side with lobulate apothecia; B-C $-E$. tenuis (B, Spielmann 11213, CGMS; C, Lücking 40067), showing upper side with apothecia and numerous phyllida (B), and phyllidia enlarged (C); D-E - E. aff. tenuis (Lücking 39705), showing lower side (D) and upper side (E).

greenish when wet, matte; margin arachnoid-pruinose. Lobules generally absent, rarely marginal in older parts. Medulla rather compact, white, $\mathrm{KC}+$ pink. Cephalodia (with Nostoc) internal, globose to flattened, to $0.4 \mathrm{~mm}$ wide, widely scattered. Lower surface smooth at margin, rugose, verrucose inward, thinly tomentose, with hairs in short fascicules, light brown-cream-colored. Rhizines simple, flaring, evenly scattered, to $1.5 \mathrm{~mm}$ long, brown, and darkening inward. Apothecia frequent but occasionally absent, laminal, scattered to abundant, to $5 \mathrm{~mm}$ in diam., margin shallowly to more rarely deeply crenulated, marginal cortex pruinose, and \pm rough. Upper cortex paraplectenchymatous, 20-30 $\mu \mathrm{m}$ thick, homogeneous, consisting of 4-6 cell layers. Photobiont layer 15-30 $\mu \mathrm{m}$ thick, its cells $\sim 6 \mu \mathrm{m}$ diam. Medulla $60-100(120) \mu \mathrm{m}$ thick. Lower cortex paraplectenchymatous, 15-20 $\mu \mathrm{m}$ thick, with 3 cell layers; surface papillose to microtomentose in section in between short fascicles. Apothecia hymenium to $135 \mu \mathrm{m}$ tall. Algal layer extending to the margin of apothecium. Ascospores acicular, straight to sigmoid, 1(-3)-septate, $60-75 \times 3 \mu \mathrm{m}, \sim 20-25$ times as long as broad. 
Secondary chemistry. Gyrophoric acid and 4-O-methylgyrophoric acid.

Ecology and distribution. On hardwood trees in the Atlantic-Gulf Coastal Plain in North America, also known from the Antilles and reported from Panama (Büdel et al. 2000).

Comments. While E. ravenelii has been considered a synonym of E. erosa [Sticta erosa] by Tuckerman (1882) and other later authors, the two species can be clearly distinguished by some morphological features, such as the absence of pruina on the upper, more distinctly scrobiculate surface of the latter, as well as a different geographical distribution (North America and Greater Antilles versus South America, respectively). Emmanuelia (as Lobaria) ravenelii has been repeatedly reported from Brazil (Kalb 1983; Brako et al. 1985). The specimens distributed in Kalb's Lichenes Neotropici (No. 237) correspond to typical E. erosa and likely to other collections reported under this name from South America.

Specimens examined. DOMINICAN REPUBLIC. La Vega: $8.8 \mathrm{~km} \mathrm{~N}$ of Constanza, $6 \mathrm{~km} \mathrm{~W}$ of La Culata toward La Cienaga de Bermudez; $5000 \mathrm{ft}$; pine woods along road and cut-over pines with Pteridium and shrubs and a few isolated pines; 28 April 1982, R. R. Harris (B, NY). USA. Alabama, Clebourne Co., Talladega National Forest, Shoal Creek, $33.733^{\circ} \mathrm{N} 85.560^{\circ} \mathrm{W}$, alt. $400 \mathrm{~m}$, forested hills, on hardwood bark, 2017 December 26, V. Charny 20171226-18 (CONN); Georgia, Candler Co., Charles Harold TNC Preserve, $0-0.25 \mathrm{mi}$ N of Salem Church Rd., W side of Stocking Head Creek, $32.4169^{\circ},-82.0692^{\circ}$, bottomland mixed hardwood forest (Nyssa, Acer, Quercus) with pine (Pinus), on Acer, 2009 December 22, J. C. Lendemer 21774 (NY \#1104321); Fifteenmile Creek Preserve, E side of Fifteenmile Creek just $\mathrm{S}$ of I-16, 32.3614 ${ }^{\circ},-82.0325^{\circ}$, mesic hardwood forest (Ilex, Nyssa, Fagus, Acer, Quercus) with pine (Pinus) and cypress (Taxodium) on bluff, on Magnolia virginiana, 2009 December 22, J. C. Lendemer 21699 (NY \#1149787); Effingham Co., Craig Barrow farm, $32.3526^{\circ},-81.4804^{\circ}$, north-aspect sand hill bluff, on bark, 2012 March 4, M. F. Hodges 8253 (NY \#2057430); Emanuel Co., Ohoopee Dunes, $32.5253^{\circ},-82.4472^{\circ}$, on bark, 2007 October 7, M. F. Hodges 1941-C (NY \#2057238); Tattnall Co., Big Hammock Natural Area, blue and yellow trails, $\sim 1 \mathrm{mi}$ E of jet of CR $441 \&$ GA $121 / 144 / 169,31.8576^{\circ},-82.0589^{\circ}$, sand hill community with oak scrub and mixed hardwoods, on Carya, 2009 December 20, J. C. Lendemer 21443 (NY \#1886944); Big Hammock Natural Area, $\sim 1$ mile southeast of Highway 121/144/169 off of Mack Phillips Road., 31.8636 ${ }^{\circ},-82.0525^{\circ}$, alt. $20 \mathrm{~m}$, dense forest with Pinus palustris, Quercus spp., and Prunus sp., on bark, 2013 March 25, T. S. Quedensley 10852 (NY \#1150285); Mississippi, Wilkinson Co., $15 \mathrm{~min}$. NW of St Francisville, between road 969 and the river, deep ravines with hardwood forest, on a deciduous tree in the bottom of the ravine, May 29 1976, E. Sérusiaux 1666 (LG); North Carolina, Craven Co., Croatan National Forest, 0-0.2 mi NE of FS 170, along tributary to Brices Creek, $1.9 \mathrm{mi} \mathrm{NE}$ of jct of FS170/FS121.2 and FS1101, $35.0369^{\circ},-77.0497^{\circ}$, alt. $4 \mathrm{~m}$, swamp forest of mixed hardwoods (Ilex, Acer, Nyssa, Liquidambar, Persea, Magnolia virginiana), on Acer, 2013 March 5, J. C. Lendemer 35039 (NY \#1865943); Dare Co., Alligator River National Wildlife Refuge, Brier Hall Rd. 0.25-0.5 mi S of jct w/ Mallard Rd., $0.25 \mathrm{mi} \mathrm{N}$ of US64, $35.8828^{\circ},-75.9375^{\circ}$, alt. $1 \mathrm{~m}$, mixed hardwood (Ilex opaca, Acer, Liquidambar, Nyssa, Persea) - Pinus swamp with understory of Cyrilla and Ilex glabra, on Acer, 2014 March 21,
E. A. Tripp 4654 (NY \#2203723); Dare Co., Alligator River National Wildlife Refuge, W of Whipping Creek Rd. $0.5 \mathrm{mi}$ $\mathrm{N}$ of jct w/ Chip Rd., $35.6753^{\circ},-75.9625^{\circ}$, alt. $0 \mathrm{~m}$, mature mixed hardwood (Nyssa, Acer, Magnolia virginiana, Liquidambar) - conifer (Chamaecyparis [dead], Taxodium and Pinus) swamp forest with Ilex glabra and Clethra understory, on large Acer, 2014 March 23, J. C. Lendemer 43114 (NY \#2203643); Graham Co., Nantahala National Forest, W of Powell Branch at confluence with Fontana Lake, terminus of Cable Cove Road (CR 1287) at Cable Cove Boat Launch, $35.4372^{\circ},-83.7481^{\circ}$, alt. 527, stream ravine with acid hardwood-conifer forest, on poison ivy, 2016 March 18, R. C. Harris 61074 (NY \#2467099); Washington Co., Bull Neck Swamp, Deep Creek Rd. $0.5 \mathrm{mi}$ $\mathrm{N}$ of bridge over Deep Creek, $35.9372^{\circ},-76.3992^{\circ}$, alt. $0 \mathrm{~m}$, mixed hardwood (Nyssa, Acer, Magnolia virginiana)-Taxodium swamp forest, on base of Nyssa, 2014 March 22, W. R. Buck 63035 (NY \#2327942); South Carolina, McCormick Co., Sumter National Forest, Stevens Creek Heritage Preserve, N of SSR 88, $\sim 1.5 \mathrm{mi} \mathrm{NE}$ of Clarks Hill, $33.6872^{\circ},-82.1614^{\circ}$, alt. $100 \mathrm{~m}$, mesic mixed hardwood bluff forest, on rock, 2010 March 11, R. C. Harris 55880 (NY \#1148729).

Molecular data. Yes.

Emmanuelia tenuis (Vain.) Lücking, Moncada \& Gumboski, comb. nov.

(Fig. 7B-C)

\section{MycoBank MB 834655}

Basionym: Lobaria tenuis Vain., Acta Soc. Fauna Fl. Fenn. 7(1): 199. 1890.

Types: Brazil, Minas Gerais: Sitio; 1000 m; 1885, Vainio 717 (TUR-V10691 - lectotype!; TUR-V10691a - isolectotype!; M-M0024301 - isolectotype!). Minas Gerais: Sitio; 1000 m; 1885, Vainio 727 (TUR-V10692 - paratype!; TUR-V10692a - paratype!).

$\equiv$ Ricasolia tenuis (Vain.) Stizenb., Flora 81: 111. 1895.

Diagnostic description. Primary photobiont a trebouxioid alga. Thallus medium-sized, rather closely adnate, composed of irregularly arranged to somewhat radiating lobes. Lobes intermediate, up to $7 \mathrm{~mm}$ wide, sinuose with rounded to truncate apices. Upper surface \pm even, glabrous. Phyllidia abundant, marginal, elongate and usually branched. Lower surface thinly tomentose except for narrow, bare, whitish marginal zone, tomentum greyish brown. Apothecia rare, laminal, to $3 \mathrm{~mm}$ in diam., margin strongly prominent, shallowly to deeply crenulate. Ascospores acicular, straight to slightly curved or sigmoid, $1(-3)$-septate, $55-70 \times 3-3.5 \mu \mathrm{m}, \sim 15-20$ times as long as broad.

\section{Secondary chemistry. Gyrophoric acid (major).}

Comments. For a detailed discussion, see under E. lobulifera (above). The correct application of this name remains somewhat uncertain. In our phylogeny, specimens with marginal phyllidia are found in two different clades: one small separate clade $(37504,39705)$ and one larger clade intermingled with non-phyllidiate specimens identified as E. elaeodes (37502, 37544b, 40067). The two differ in the size and disposition of the phyllidia, which in the small separate clade are larger and oriented in the same direction as the lobes, and in the larger mixed clade are smaller and somewhat obliquely arranged. Both taxa were 
found sympatric at one locality. Vainio's original material appears to correspond to the form with smaller, obliquely arranged phyllidia, which would mean that the separate clade, currently labeled aff. tenuis, requires a name.

Specimens examined. BRAZIL. Rio Grande do Sul: Caraá, Caraá Environmental Protection Area; $29^{\circ} 42^{\prime} \mathrm{S}, 50^{\circ} 17^{\prime} \mathrm{W}, 410 \mathrm{~m}$; well-preserved Atlantic Forest fragment; 21 September 2014, Lücking 37502, 37544b (B, HAS). Santa Catarina: São Francisco do Sul, Parque Estadual Acarai; $26^{\circ} 16^{\prime} \mathrm{S}, 48^{\circ} 32^{\prime} \mathrm{W}$, sea level; rather well preserved coastal Restinga forest; 8 October 2015, Lücking 40067 (B, JOI).

[aff. tenuis]. [Brazil] Espírito Santo: Santa Teresa, Estação Biológica de Santa Lúcia; $19^{\circ} 58^{\prime} \mathrm{S}, 40^{\circ} 32^{\prime} \mathrm{W}, 500-600$ m; rather well preserved Atlantic Forest remnant; 28-30 September 2015, Lücking 39705 (B, ISE). Santa Catarina: São Francisco do Sul, Parque Estadual Acarai; $26^{\circ} 16^{\prime} \mathrm{S}, 48^{\circ} 32^{\prime} \mathrm{W}$, sea level; rather well preserved coastal Restinga forest; 8 October 2015, Lücking 37504 (B, JOI).

\section{Molecular data. Yes.}

\section{Key to the species of Emmanuelia}

1 With laminal (to marginal) phyllidia; apothecia rare ...2

1 Without phyllidia; apothecia common.........4

2(1) Phyllidia mostly laminal, shortly squamiform, unbranched to sparsely branched; lobe surface uneven to shallowly scrobiculate; southeastern North America . . . E. lobulifera

2(1) Phyllidia mostly marginal, elongate, much branched; lobe surface \pm even; South America............ 3

3(2) Phyllidia rather large, oriented in the same way as the lobes ................. aff. tenuis

3(2) Phyllidia smaller, obliquely oriented ...... E. tenuis

4(1) Lobe underside becoming purplish red in the herbarium; lobes rather broad $(5-10 \mathrm{~mm})$, radiating, with rounded apices and \pm even surface; apothecia small (1-2 mm), with entire to crenulate margins; South America .....

E. cuprea

4(1) Lobe underside whitish to beige, with tomentum light to dark brown; lobes variable; apothecia larger

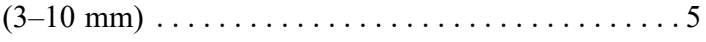

5(4) Medulla C- (lacking gyrophoric acid); lobes narrow (3-5 mm), irregularly arranged, with rounded to somewhat truncated apices and \pm even surface; apothecia large (up to $10 \mathrm{~mm}$ diam.), with lobulate margins; South America ................... p. pseudolivacea

5(4) Medulla $\mathrm{C}+$ pinkish red (gyrophoric acid) . . . . . 6

6(5) Lobe surface typically with numerous hemispherical, dendriscocauloid cephalodia; lobes narrow (3-5 mm), radiating, with rounded to somewhat truncated, crenulate to lobulate apices and uneven to shallowly scrobiculate surface; Galapagos, South America and southeastern North America ................. E. ornata

6(5) Cephalodia internal if present $\ldots \ldots \ldots \ldots \ldots \ldots 7$

7(6) Ascospores 5-septate; thallus closely adnate, with very narrow lobes (up to $3 \mathrm{~mm}$ ); Mexico ... E. conformis

7(6) Ascospores 1-3-septate; thallus closely to loosely adnate, with broader lobes (above $3 \mathrm{~mm}$ and to $20 \mathrm{~mm}$ ) ...8

8(7) Lobe surface shallowly to distinctly scrobiculate; lobes narrow (to $5 \mathrm{~mm}$ ), \pm radiating .............
8(7) Lobe surface \pm even; lobes broader (5-20 mm), radiating to irregularly arranged $\ldots \ldots \ldots \ldots \ldots \ldots \ldots$

9(8) Lobe surface pruinose especially towards tips, shallowly scrobiculate; apothecia small (up to $3 \mathrm{~mm}$ ), with entire to crenulate margins; southeastern North America, extending into the Greater Antilles........... E. ravenelii

9(8) Lobe surface epruinose, distinctly scrobiculate; apothecia larger (up to $5 \mathrm{~mm}$ ), with lobulate margins (flower-like); South America ................. erosa

10(8) Lower tomentum forming a very regular dark brown, linear pattern except for abruptly bare marginal zone (similar to Yoshimuriella); apothecia with large lobules; Colombia ..................... E. excisa

10(8) Lower tomentum gradually thinning towards the margins, light to greyish brown, often with broader bare marginal zone; apothecia variable............... 11

11(10) Apothecia medium-sized (3-5 mm), with entire to crenulate margins; lobes papery, intermediate $(5-7 \mathrm{~mm})$; South America ................... E. elaeodes

11(10) Apothecia large $(5-10 \mathrm{~mm})$, with lobulate margins (flower-like); lobes leathery, broad (7-20 mm); South America ..................... 12

12(11) Lobes up to $12 \mathrm{~mm}$ broad, with numerous pycnidial warts on the surface; apothecia horizontal; ascospores up to $70 \times 3 \mu \mathrm{m} \ldots \ldots \ldots \ldots \ldots$ E. americana

12(11) Lobes up to $20 \mathrm{~mm}$ broad, lacking or with few pycnidial warts; apothecia obliquely oriented; ascospores up to 90 $\times 4 \mu \mathrm{m} \ldots \ldots \ldots \ldots . \ldots \ldots$. patinifera

\section{Acknowledgements}

We thank Zach Muscavitch (UConn) for his assistance in the performance of thin-layer chromatography. We are grateful to Jason Hollinger for providing valuable material and photographs for this study, and to the herbarium curators of BG, NYBG and UBC for arranging for loans of material. The Galapagos Lichen Inventory is part of the 'Biodiversidad Genética del Ecuador' national biodiversity assessment led by the Instituto Nacional de Biodiversidad del Ecuador (INABIO). For research and specimen permits we are particularly indebted to Danny Rueda, Daniel Lara Solís, Galo Quedaza and Victor Carrión from the Directorate of Galapagos National Park (DPNG), and to Diego Inclán, Francisco Prieto and Rosa Batallas (INABIO). We further acknowledge the support of successive CDF science directors (most recently Maria-José Barragan Paladines). AS acknowledges financial support from FRIA, a grant of the Fonds de la Recherche Scientifique - FNRS (F.R.S.-FNRS). This study was also supported by NSF DEB-1354631 to the University of Connecticut (BG) and NSF DEB-1354884 to The Field Museum (RL, BM), by the Department of Ecology and Evolutionary Biology (UConn), and by the Summer Research Fellowship Program at UConn to DP. This publication is contribution number 2315 of the Charles Darwin Foundation for the Galapagos Islands.

\section{References}

Avise, J. C. \& Johns, G. C. 1999. Proposal for a standardized temporal scheme of biological classification for extant species. Proceedings of the National Academy of Sciences of the United States of America 96: 7358-7363.

Batalha-Filho, H., Fjeldså, J., Fabre, P. H. \& Miyaki, C. Y. 2013. Connections between the Atlantic and the Amazonian forest avifaunas 
represent distinct historical events. Journal of Ornithology 154: 41-50.

Brako, L., Dibben, M. J. \& Amaral, I. D. 1985. Preliminary notes on the macrolichens of Serra do Cachimbo, northcentral Brazil. Acta Amazonica 15: 123-136.

Brotzu, P., Melluso, L., Bennio, L., Gomes, C. B., Lustrino, M., Morbidelli, L., Morra, V., Ruberti, E., Tassinari, C. \& d'Antonio, M. 2007. Petrogenesis of the Early Cenozoic potassic alkaline complex of Morro de São João, southeastern Brazil. Journal of South American Earth Sciences 24: 93-115.

Büdel, B., Meyer, A., Salazar, N., Zellner, H., Zotz, G. \& Lange, O. L. 2000. Macrolichens of montane rain forests in Panama, Province Chiriquí. The Lichenologist 32: 539-551.

Clement, M., Posada, D. \& Crandall, K. A. 2000. TCS: a computer program to estimate gene genealogies. Molecular Ecology 9: 1657-1659.

Colombo, A. F. \& Joly, C. A. 2010. Brazilian Atlantic Forest lato sensu: the most ancient Brazilian forest, and a biodiversity hotspot, is highly threatened by climate change. Brazilian Journal of Biology 70: 697-708.

Cornejo, C., Derr, C. \& Dillman, K. 2017. Ricasolia amplissima (Lobariaceae): One species, three genotypes and a new taxon from south-eastern Alaska. The Lichenologist 49: 579-596.

Cubero, O. F., Crespo, A., Fatehi, J. \& Bridge, P. D. 1999. DNA extraction and PCR amplification method suitable for fresh, herbarium-stored, lichenized, and other fungi. Plant Systematics and Evolution 216: 243-249.

Darriba, D., Taboada, G. L., Doallo, R. \& Posada, D. 2012. jModelTest 2: more models, new heuristics and parallel computing. Nature Methods 9: 772 .

Drummond, A. J. \& Rambaut, A. 2007. BEAST: Bayesian evolutionary analysis by sampling trees. BMC evolutionary biology 7: 214 .

Etayo, J., Flakus, A. \& Kukwa, M. 2018. Three new lichenicolous species of the genus Plectocarpon (Ascomycota: Lecanographaceae) discovered in the Bolivian Andes. Phytotaxa 357: 275-283.

Fouquet, A., Loebmann, D., Castroviejo-Fisher, S., Padial, J. M., Orrico, V. G., Lyra, M. L., Roberto, I. J., Kok, P. J., Haddad, C. F. \& Rodrigues, M. T. 2012. From Amazonia to the Atlantic forest: Molecular phylogeny of Phyzelaphryninae frogs reveals unexpected diversity and a striking biogeographic pattern emphasizing conservation challenges. Molecular Phylogenetics and Evolution 65: 547-561.

Galloway, D. J. 2015. Contributions to a history of New Zealand lichenology 5*. James Murray (1923-1961). Phytotaxa 198: 1-67.

Galloway, D. J. \& Elix, J. A. 2013. Reinstatement of Crocodia Link (Lobariaceae: Ascomycota) for five species formerly included in Pseudocyphellaria Vain. Australasian Lichenology 72: 32-42.

Gardes, M. \& Bruns, T. D. 1993. ITS primers with enhanced specificity for basidiomycetes-application to the identification of mycorrhizae and rusts. Molecular ecology 2: 113-118.

Gernhard, T. 2008. The conditioned reconstructed process. Journal of Theoretical Biology 253: 769-778.

Guindon, S., Dufayard, J. F., Lefort, V., Anisimova, M., Hordijk, W. \& Gascuel, O. 2010. New algorithms and methods to estimate maximum-likelihood phylogenies: Assessing the performance of PhyML 3.0. Systematic Biology 59: 307-321.

Högnabba, F., Stenroos, S. \& Thell, A. 2009. Phylogenetic relationship and evolution of photobiont associations in the Lobariaceae (Peltigerales, Lecanoromycetes, Ascomycota). Bibliotheca Lichenologica 100: $157-187$.

Hoorn, C., Wesselingh, F. P., Ter Steege, H., Bermudez, M. A., Mora, A., Sevink, J., Sanmartín, I., Sanchez-Meseguer, A., Anderson, C. L., Figueiredo, J. P. \& Jaramillo, C., 2010. Amazonia through time: Andean uplift, climate change, landscape evolution, and biodiversity. Science 330: 927-931.

Jordan, W. P. 1972. Erumpent cephalodia, an apparent case of phycobial influence on lichen morphology. Journal of Phycology 8: 112-117.

Jordan, W. P. 1973. The genus Lobaria in North America North of Mexico. The Bryologist 76: 225-251.
Käffer, M. I., Ganade, G. \& Marcelli, M. P. 2009. Lichen diversity and composition in Araucaria forests and tree monocultures in southern Brazil. Biodiversity and Conservation 18: 3543-3561.

Käffer, M. I., Dantas, R. V. \& Martins, S. M. d. A., 2016. Characterization of the epiphytic lichen vegetation in a riparian forest in southern Brazil. Plant Ecology and Evolution 149: 92-100.

Kalb, K. 1983. Lichenes Neotropici, Fascikel VI (No. 201-250). Published by the author, Neumarkt/OPf., Germany.

Katoh, K. 2002. MAFFT: a novel method for rapid multiple sequence alignment based on fast Fourier transform. Nucleic Acids Research 30: 3059-3066.

Katoh, K., Asimenos, G. \& Toh, H. 2009. Multiple alignment of DNA sequences with MAFFT. Methods in molecular biology 537: 39-64.

Kraichak, E., Crespo, A., Divakar, P. K., Leavitt, S. D. \& Lumbsch, H. T. 2017. A temporal banding approach for consistent taxonomic ranking above the species level. Scientific Reports 7: 1-7.

Kraichak, E., Huang, J.-P., Nelsen, M., Leavitt, S. D. \& Lumbsch, H. T. 2018. A revised classification of orders and families in the two major subclasses of Lecanoromycetes (Ascomycota) based on a temporal approach. Botanical Journal of the Linnean Society 188: 233-249.

Lanfear, R., Calcott, B., Ho, S. Y. W. \& Guindon, S. 2012. PartitionFinder: Combined Selection of Partitioning Schemes and Substitution Models for Phylogenetic Analyses. Molecular Biology and Evolution 29: 1695-1701.

Lanfear, R., Frandsen, P. B., Wright, A. M., Senfeld, T. \& Calcott, B. 2016. Partition- Finder 2: New methods for selecting partitioned models of evolution for molecular and morphological phylogenetic analyses. Molecular Biology and Evolution 34: 772-773.

Lehnen, P. G., Käffer, M. I., Lucheta, F. \& Schmitt, J. L. 2017. Estrutura da comunidade de liquens corticícolas em área urbana e rural no município de Novo Hamburgo, Rio Grande do Sul, Brasil. Iheringia. Série Botânica 72: 66-74.

Leigh, J. W. \& Bryant, D. 2015. POPART: Full-feature software for haplotype network construction. Methods in Ecology and Evolution 6: $1110-1116$.

Lohtander, K., Oksanen, I. \& Rikkinen, J. 2002. A phylogenetic study of Nephroma (lichen-forming Ascomycota). Mycological Research 106: 777-787.

Lücking, R. 2019. Stop the Abuse of Time! Strict Temporal Banding is not the Future of Rank-Based Classifications in Fungi (Including Lichens) and Other Organisms. Critical Reviews in Plant Sciences 38: 199-253.

Lücking, R., Dal Forno, M., Moncada, B., Coca, L. F., Vargas-Mendoza, L. Y., Aptroot, A., Arias, L. J., Besal, B., Bungartz, F., Cabrera-Amaya, D. M., Cáceres, M. E. S., Chaves, J. L., Eliasaro, S., Gutiérrez, M. C., Hernández-M., J. E., Herrera-Campos, M. A., Holgado-Rojas, M. E., Jonitz, H., Kukwa, M., Lucheta, F., Madriñán, S., Marcelli, M. P., Martins, S. M. A., Mercado-Díaz, J. A., Molina, J. A., Morales, E. A., Nelson, P. R., Nugra, F., Ortega, F., Paredes, T., Patiño, A. L., Peláez-Pulido, R. N., Pérez-Pérez, R. E., Perlmutter, G. B., Rivas-Plata, M. E., Robayo, J., Rodríguez, C., Simijaca, D. F., Soto-Medina, E., Spielmann, A. A., Suárez-Corredor, A., Torres, J. M., Vargas, C. A., Yánez-Ayabaca, A., Weerakoon, G., Wilk. K., Celis-Pacheco, M., Diazgranados, M., Brokamp, G., Borsch, T., Gillevet, P. M., Sikaroodi, M. \& Lawrey, J. D. 2017a. Turbo-taxonomy to assemble a megadiverse lichen genus: seventy new species of Cora (Basidiomycota: Agaricales: Hygrophoraceae), honouring David Leslie Hawksworth's seventieth birthday. Fungal Diversity 84: 139-207.

Lücking, R., Moncada B. \& Smith C. W. 2017b. The genus Lobariella (Ascomycota: Lobariaceae) in Hawaii: late colonization, high inferred endemism and three new species resulting from 'micro-radiation'. The Lichenologist 49: 673-691.

Lumbsch, T. H. \& Leavitt, S. D. 2019. Introduction of subfamily names for four clades in Cladoniaceae and Peltigeraceae (Lecanoromycetes). Mycotaxon 134: 271-273.

Machado, L. F., Loss, A. C., Paz, A., Vieira, E. M., Rodrigues, F. P. \& Marinho-Filho, J. 2018. Phylogeny and biogeography of Phyllomys (Rodentia: Echimyidae) reveal a new species from the 
Cerrado and suggest Miocene connections of the Amazon and Atlantic Forest. Journal of Mammalogy 99: 377-396.

Magain, N., Goffinet, B. \& Sérusiaux, E. 2012. Further photomorphs in the lichen family Lobariaceae from Reunion (Mascarene archipelago) with notes on the phylogeny of Dendriscocaulon cyanomorphs. The Bryologist 115: 243-254.

Magain, N. \& Sérusiaux, E. 2015. Dismantling the treasured flagship lichen Sticta fuliginosa (Peltigerales) into four species in Western Europe. Mycological Progress 14: 1-33.

McCune, B., Rosentreter, R., Spribille, T., Breuss, O. \& Wheeler, T. B. 2014. Montana Lichens: An Annotated List. Vol. 2. Northwest Lichenologists, Corvallis, Oregon.

Miadlikowska, J., Kauff, F., Hofstetter, V., Fraker, E., Grube, M., Hafellner, J., Reeb, V., Hodkinson, B. P., Kukwa, M., Lücking, R., Hestmark, G., Garcia Otalora, M., Rauhut, A., Büdel, B., Scheidegger, C., Timdal, E., Stenroos, S., Brodo, I., Perlmutter, G., Ertz, D., Diederich, P., Lendemer, J. C., May, P., Schoch, C. L., Arnold, A. E., Gueidan, C., Tripp, E., Yahr, R., Robertson, C. \& Lutzoni, F. 2006. New insights into classification and evolution of the Lecanoromycetes (Pezizomycotina, Ascomycota) from phylogenetic analyses of three ribosomal RNA- and two protein-coding genes. Mycologia 98: 1088-1103.

Miller, M. A., Pfeiffer, W. \& Schwartz, T. 2010. Creating the CIPRES Science Gateway for inference of large phylogenetic trees. 2010 Gateway Computing Environments Workshop (GCE) IEEE: 1-8.

Moncada, B., Lücking, R. \& Betancourt-Macuase, L. 2013. Phylogeny of the Lobariaceae (lichenized Ascomycota: Peltigerales), with a reappraisal of the genus Lobariella. The Lichenologist 45: 203-263.

Moore, B. J. 1969. Lobaria lobulifera, a New Species from the Southeastern United States. The Bryologist 72: 404-406.

Müller, J. 1891. Lichenologische Beiträge XXXV. Flora (Regensburg) 74: 371-382.

Orange, A., James, P. W. \& White, F. J. 2001. Microchemical methods for the identification of lichens. London: British Lichen Society.

Osorio, H. S. \& Fleig, M. 1987. Contribution to the lichen flora of Brazil. XIX. New or additional records from Santa Maria, Rio Grande do Sul State. Comunicaciones Botanicas del Museo de Historia Natural de Montevideo 5: 1-8.

Penn, O., Privman, E., Ashkenazy, H., Landan, G., Graur, D. \& Pupko, T. 2010a. GUIDANCE: A web server for assessing alignment confidence scores. Nucleic Acids Research 38: 23-28.

Penn, O., Privman, E., Landan, G., Graur, D. \& Pupko, T. 2010b. An alignment confidence score capturing robustness to guide tree uncertainty. Molecular Biology and Evolution 27: 1759-1767.

Peucker-Ehrenbrink, B. \& Miller, M. W. 2007. Quantitative bedrock geology of Brazil. Geochemistry, Geophysics, Geosystems 8(5): 8000.

Rambaut, A., Suchard, M. A., Xie, D. \& Drummond, A. J. 2014. Tracer v1.6. Retrieved from http://tree.bio.ed.ac.uk/software/tracer (accessed in May 2020).

Sela, I., Ashkenazy, H., Katoh, K. \& Pupko, T. 2015. GUIDANCE2: Accurate detection of unreliable alignment regions accounting for the uncertainty of multiple parameters. Nucleic Acids Research 43: W7-W14.

Schmull, M., Miadlikowska, J., Pelzer, M., Stocker-Wörgötter, E., Hofstetter, V., Fraker, E., Hodkinson, B. P., Reeb, V., Kukwa, M., Lumbsch, H. T., Kauff, F. \& Lutzoni, F. 2011. Phylogenetic affiliations of members of the heterogeneous lichen- forming fungi of the genus Lecidea sensu Zahlbruckner (Lecanoromycetes, Ascomycota). Mycologia 103: 983-1003.
Sipman, H. J. M. 1993. Lichenotheca Latinoamericana a museo botanico berolinensi edita, fasciculum secundum. Willdenowia 23: 305-314.

Stamatakis, A. 2014. RAxML version 8: a tool for phylogenetic analysis and post-analysis of large phylogenies. Bioinformatics 30: $1312-1313$.

Stenroos, S., Stocker-Wörgötter, E., Yoshimura, I., Myllys, L., Thell, A. \& Hyvönen, J. 2003. Culture experiments and DNA sequence data confirm the identity of Lobaria photomorphs. Canadian Journal of Botany 81: 232-247.

Stizenberger, E. 1895. Die Grübchenflechten (Stictei) und ihre geographische Verbreitung. Flora, Jena 81: 88-150.

Simon, A., Goffinet, B., Magain N. \& Sérusiaux, E. 2018. High diversity, high insular endemism and recent origin in the lichen genus Sticta (lichenized Ascomycota, Peltigerales) in Madagascar and the Mascarenes. Molecular Phylogenetics and Evolution 122: 15-28.

Takahashi, K., Wang, L.-S., Tsubota, H. \& Deguchi, H. 2006. Photosymbiodemes Sticta wrightii and Dendriscocaulon sp. (lichenized Ascomycota) from Yunnan, China. Journal of the Hattori Botanical Laboratory 100: 783-796.

Thomas, M. A., Ryan, D. J., Farnden, K. J. F. \& Galloway, D. J. 2002. Observations on phylogenetic relationships within Lobariaceae Chevall. (Lecanorales, Ascomycota) in New Zealand, based on ITS-5.8S molecular sequence data. Bibliotheca Lichenologica 82: 123-138.

Tønsberg, T., Blom, H., Goffinet, B., Holtan-Hartwig, J. \& Lindblom, L. 2016. The cyanomorph of Ricasolia virens comb. nov. (Lobariaceae, lichenized Ascomycetes). Opuscula Philolichenum 15: 12-21.

Tuckerman, E. 1882. A Synopsis of the North American Lichens. Part 1. Boston, Massachusetts, USA, p. 176.

White, T. J., Bruns, S., Lee, S. \& Taylor, J. 1990. Amplification and direct sequencing of fungal ribosomal RNA genes for phylogenetics. PCR protocols: A guide to methods and applications. 18: 315-322.

Widhelm, T. J., Grewe, F., Huang, J. P., Mercado-Díaz, J. A., Goffinet, B., Lücking, R., Moncada, B., Mason-Gamer, R. \& Lumbsch, H. T. 2019. Multiple historical processes obscure phylogenetic relationships in a taxonomically difficult group (Lobariaceae, Ascomycota). Scientific Reports 9: 8968.

Wiklund, E. \& Wedin, M. 2003. The phylogenetic relationships of the cyanobacterial lichens in the Lecanorales suborder Peltigerineae. Cladistics 19: 419-431.

Yoshimura, I. 1971. The genus Lobaria of Eastern Asia. Journal of the Hattori Botanical Laboratory 34: 231-364.

Yoshimura, I. 1998. Lobaria in Latin America: taxonomic, geographic and evolutionary aspects. In: Marcelli, M. P. \& Seaward, M. R. D. (eds) Lichenology in Latin America: History, Current Knowledge and Applications, pp. 129-134. CETESB - Companhia de Tecnologia de Saneamento Ambiental, São Paulo.

Yoshimura, I. \& Osorio, H. 1975. Notes on Lobaria cuprea with purple pigment. Journal of the Hattori Botanical Laboratory 39: 263-268.

Yu, G., Smith, D. K., Zhu, H., Guan, Y. \& Lam, T. T.-Y. 2017. GGTREE: an $R$ package for visualization and annotation of phylogenetic trees with their covariates and other associated data. Methods in Ecology and Evolution 8: 28-36.

Yule, G. 1924. A mathematical theory of evolution, based on the conclusions of Dr. JC Willis. FRS Philosophical Transactions of the Royal Society of London B213: 21-87.

Zoller, S., Scheidegger, C. \& Sperisen, C. 1999. PCR primers for the amplification of mitochondrial small subunit ribosomal DNA of lichen-forming ascomycetes. The Lichenologist 31: 511-516. 